NBER WORKING PAPER SERIES

\title{
WILL DIVESTMENT FROM EMPLOYMENT-BASED HEALTH INSURANCE SAVE EMPLOYERS MONEY? THE CASE OF STATE AND LOCAL GOVERNMENTS
}

\author{
Jeremy D. Goldhaber-Fiebert
}

David M. Studdert

Monica S. Farid

Jay Bhattacharya

Working Paper 20222

http://www.nber.org/papers/w20222

\author{
NATIONAL BUREAU OF ECONOMIC RESEARCH \\ 1050 Massachusetts Avenue \\ Cambridge, MA 02138 \\ June 2014
}

The authors gratefully acknowledge Daniel R. Austin, Anna Luan, and Louise L. Wang, co-authors along with Dr. Bhattacharya on an earlier paper in Health Affairs that examined the effect of shifts to employer insurance premiums. These authors generously shared Stata code that formed the basis for the ACA subsidy and cost-sharing calculations used in our work. The authors also wish to thank the Stanford Health Policy faculty and trainees for insightful comments and questions during the development of this work. Dr. Goldhaber-Fiebert was supported in part by the National Institutes of Health Nation Institute on Aging (K01-AG037593; PI: Goldhaber-Fiebert). Dr. Bhattacharya also thanks the National Institute on Aging for support (P01-AG05842 and R37-AG036791). The views expressed herein are those of the authors and do not necessarily reflect the views of the National Bureau of Economic Research.

NBER working papers are circulated for discussion and comment purposes. They have not been peerreviewed or been subject to the review by the NBER Board of Directors that accompanies official NBER publications.

(C) 2014 by Jeremy D. Goldhaber-Fiebert, David M. Studdert, Monica S. Farid, and Jay Bhattacharya. All rights reserved. Short sections of text, not to exceed two paragraphs, may be quoted without explicit permission provided that full credit, including $\mathbb{C}$ notice, is given to the source. 
Will Divestment from Employment-Based Health Insurance Save Employers Money? The Case of State and Local Governments

Jeremy D. Goldhaber-Fiebert, David M. Studdert, Monica S. Farid, and Jay Bhattacharya NBER Working Paper No. 20222

June 2014

JEL No. H51,H7,I1,J45

\begin{abstract}
Reforms introduced by the Affordable Care and Patient Protection Act (ACA) build new sources of coverage around employment-based health insurance. But what if firms find it cheaper to have their employees obtain insurance from these sources, even after accounting for penalties (for non-provision of insurance) and employee bonuses (to ensure the shift is cost neutral for them)? State and local governments (SLGs) have strong incentives to consider the economics of such "divestment"; many have large unfunded benefits liabilities. We investigated whether SLGs would save under two scenarios: (1) shifting all employees and under-65-retirees to alternative sources of coverage; (2) shifting only employees whose household incomes indicate they would be eligible for federally subsidized coverage and all under-65-retirees. Full divestment would cost SLGs more than they currently pay, due primarily to penalty costs. Selective divestment could save SLGs nearly $\$ 129$ billion over 10 years at the expense of the federal government.
\end{abstract}

Jeremy D. Goldhaber-Fiebert

117 Encina Commons

CHP/PCOR

Stanford University

Stanford, CA 94305-6019

jeremygf@stanford.edu

David M. Studdert

117 Encina Commons

CHP/PCOR

Stanford University

Stanford, CA 94305-6019

studdert@stanford.edu
Monica S. Farid

117 Encina Commons

CHP/PCOR

Stanford University

Stanford, CA 943305-6019

msfarid@nber.org

Jay Bhattacharya

117 Encina Commons

CHP/PCOR

Stanford University

Stanford, CA 94305-6019

and NBER

jay@stanford.edu

A data appendix is available at:

http://www.nber.org/data-appendix/w20222 


\section{INTRODUCTION}

Sweeping national policy reforms often reset the division of fiscal responsibilities between the public and private sectors, and between different levels of government.[1] They may also create strong incentives for cost shifting, particularly in immediate post-reform periods when "loopholes" abound in evolving regulations.[2] The Patient Protection and Affordable Care Act (ACA) is no exception. The federal government's role in healthcare financing expands substantially as it takes on subsidies and cost-sharing for lower income households, as well as the lion's share of the costs of Medicaid expansions.

The enhanced role for federal government financing has the potential to chill employers' willingness to offer health insurance.[3] With coverage for most workers and their families available through the health insurance exchanges or expanded Medicaid programs, it may be appealing for firms to curtail their own offerings. For this to be a cost-saving move, however, any savings from having employees obtain insurance elsewhere would need to exceed penalties levied under the ACA. ${ }^{1}$ Such health insurance "divestment" by employers is not what the ACA's architects intended, but the potential for firms to have financial incentives to pursue it cannot be ignored.

One large group of employers with pressing reasons to consider health insurance divestment is state and local government (SLG). Of critical importance, SLGs were particularly hard hit by the most recent financial crisis. Between 2009 and 2012, budget shortfalls among state governments exceeded $\$ 540$ billion [4], prompting deep cuts to spending and services. Although the fiscal position of SLG has generally improved since 2012, many will take years to return to a stable financial position.[4]

Health insurance benefits constitute a substantial component of SLG budgets. In 2013, most SLGs offered health insurance to their employees, and many extended benefits to retirees under age 65, but continuing to do so will be challenging.[5] A 2010 Pew Center report estimated that states' obligations to public sector retiree healthcare benefits exceeded states' assets by $\$ 627$ billion.[6-8] A more recent Pew Center report co-commissioned with the MacArthur foundation finds that SLGs offer more generous insurance than large private employers, covering a greater proportion of their employee's healthcare costs and being more likely to offer first-dollar coverage.[9] Hence, the weight of SLG healthcare obligations in their current form is particularly heavy.

Would SLGs alleviate their budgetary pressures by shifting current and retired employees into federally-subsidized health insurance plans? If so, how much money might they save? We addressed these questions by combining and analyzing data from three national surveys. We began by estimating the costs to SLGs of continuing to offer coverage in the usual way. Next, we

\footnotetext{
${ }^{1}$ In addition to the incentives of capturing subsidies and cost-sharing, an important example of how the ACA may raise the cost of maintaining employer sponsored insurance plans relative to cost prior to the ACA is the so-called "Cadillac tax" which taxes overly generous plans. Press coverage has highlighted the risk of SLG insurance plans in facing the "Cadillac tax"; and it is likely given SLG healthcare plan generosity that it will be felt there first. Yet, because the threshold at which the "Cadillac tax" kicks in is indexed to the overall CPI and medical costs have historically grown much more quickly that the overall CPI, it is quite possible that many employers - even non-SLGs - will eventually face the "Cadillac tax" themselves and hence greater incentives to shift away from employer sponsored coverage or at least to reduce the generosity of the plans they offer.
} 
estimated whether SLGs would save by dropping employment-based insurance entirely and supporting employees and retirees to obtain coverage elsewhere. We then estimated potential savings from selectively shifting defined subgroups of beneficiaries to alternative coverage sources. Finally, we considered possible legal barriers to these moves by SLGs, particularly the selective shifting of current employees onto the ACA exchanges.

Our findings should provide useful information to SLGs considering their options in the wake of the ACA. Since savings to SLGs are achieved largely by shifting costs to the federal government, our estimates are also relevant to ongoing debates about projected costs of ACArelated reforms to the federal government.

\section{A. The Divestment Calculus}

The calculus of divestment is complex for any employer and may be particularly so for SLGs. It involves evaluating the complex interplay between financial and non-financial incentives for and against such action that flow from a variety of sources, accounting for demand, political climates and the potential for policies to be changed through federal regulatory, legislative or legal processes.

The ACA does not establish special rules for SLGs; essentially, the law treats them like any other employer. ${ }^{2}$ Thus, under the ACA's “play-or-pay” regime, if an SLG with at least 50 full-time equivalent workers does not offer at least one coverage option to every full-time employee, and an employee obtains subsidized coverage through an individual exchange, the employer must pay a $\$ 2,000$ penalty for each full-time employee above the first 30. Alternatively, if an SLG with 50 full-time equivalent employees offers coverage but employees choose instead to purchase insurance on the exchange, the SLG faces a penalty if the purchase attracts a subsidy. In this case, the SLG faces the lesser of two penalties: \$3,000 per employee who purchases subsidized coverage or $\$ 2,000$ for all full-time employees above the first 30 .

Nor does the ACA stipulate special rules or exceptions for SLG employees. They may purchase health insurance offered on the exchange, or enroll in Medicaid provided they meet eligibility criteria. Income thresholds for Medicaid eligibility vary by state, but the ACA sets a floor: states implementing the expansions must accept households with incomes below $138 \%$ of the Federal Poverty Level (FPL), which in 2013 corresponded to \$15,856 for an individual or \$26,951 for a family of three. Households with incomes between 138\% and 400\% FPL are eligible for subsidies and cost-sharing for exchange-purchased plans, calculated on a sliding scale. ${ }^{3}$

For SLGs and other employers, shifting employees to Medicaid and exchange-purchased plans may be fiscally attractive. However, the calculus is not straightforward. It depends on several factors - principally, how many employees are Medicaid eligible, how many are eligible for subsidies and cost-sharing (and at what level), and the amount of any applicable penalties. Furthermore, these costs and benefits depend upon whether particular states have undertaken

\footnotetext{
${ }^{2}$ Rules described in this section come from various provisions of [1] The Patient Protection and Affordable Care Act. U.S.A2010:119.

${ }^{3}$ The ACA actually specifies $133 \%$ of the federal poverty level as the Medicaid eligibility threshold, but the first 5 percentage points of income are disregarded, effectively making it $138 \%$.
} 
Medicaid expansions. These factors, and the overall cost equation, are amenable to quantitative analysis.

Other implications of health insurance divestment by SLGs - for example, political and reputational costs - are much more difficult to quantify, and we do not incorporate them directly into our estimates. However, recent developments provide some clues. A 2009 50-state survey by the US Government Accountability Office found that SLGs striving to control unfunded liabilities have introduced a variety of changes to their retiree health benefits, including alterations to plan offerings, employer contributions, and eligibility requirements.[7] In addition, recent media reports describe proposals by several cities and counties - including Chicago, Detroit, Sheboygan County (Wisconsin), and Stockton (California) - to utilize ACA provisions to reduce the costs of health insurance benefits to their retirees.[11-14] ${ }^{4}$ Yet, even with these recent developments, the prospect of firms divesting from health insurance in the presence of the ACA has been questioned on a number of grounds including the observation that even when not required, firms provided such benefits voluntarily prior to the ACA.[15]

Despite signs that SLGs are already moving to constrain health insurance benefits, we recognize that simply ceasing to offer them and pointing workers elsewhere would be an unpalatable option for most SLGs, however parlous their financial situation. This is especially true in relation to current employees. Such a move would be criticized on public policy grounds, and may have adverse effects on the health and wellbeing of the tens of millions of people who currently obtain coverage through SLG-based plans.

For these reasons, all of the health insurance divestment strategies we consider incorporate an income supplement paid by SLGs to their employees who purchase insurance on the exchanges. The purpose of these supplements is to bridge any cost differences employees may encounter (i.e., the difference between premiums in their employment-based plan and premium costs in products found on the exchange, less any subsidies received). In other words, our calculations are designed to ensure SLG employees who shift to federally subsidized forms of coverage are no worse off financially than they were under employment-based coverage.

We also recognize that forcing subgroups of employees to shift from employment-based coverage is likely to be unpopular. In the selective divestment scenarios we consider, SLGs need not impose bars on employment-based purchasing. Rather, we imagine a suite of inducements that would lead most or all members of certain subgroups to seek non employment-based coverage, and if they do, fair income supplements would be provided to make this a cost-neutral move.

In addition, income supplements will have tax consequences. Employer contributions to coverage purchased on an exchange must be paid with post-tax income, whereas traditional employer sponsored coverage can generally be made with pre-tax income. With some exceptions, employee contributions are taxable. ${ }^{5}[17,18]$ Consequently, the tax treatment of any

\footnotetext{
${ }^{4}$ We are not aware of any SLGs actively considering this strategy for current employees.

${ }^{5}$ Payments that exceed 10\% of the employee's Adjusted Gross Income (AGI) are tax deductible. Under section 125 of the Internal Revenue Code, the Internal Revenue Service also permits certain "qualified expenses”, including some medical and premium costs, to be paid on a pre-tax basis. For a discussion of "cafeteria plans" see [2] Hall M, Monahan A. Paying for Individual Health Insurance through Tax-sheltered Cafeteria Plans. Inquiry. 2010; 47(3):252-61.
} 
income supplements to SLG employees must also be considered in a divestment calculus that seeks to leave the SLG employees financially no worse off.

Finally, for a variety of reasons including their own overall strategy on healthcare for all citizens within their jurisdiction, some SLGs may simply be more inclined and ready to consider shifting their own employees towards ACA exchanges. One indication of this is whether a state has established its own insurance exchange or instead has a federal exchange imposed. Another is whether a State has taken up the ACA Medicaid expansion. Hence, we examine scenarios in which divestment strategies are confined to States that have their own exchanges, all but one having undertaken a Medicaid expansion as well.

\section{DATA AND METHODS}

\section{A. Data}

Our analyses use the Current Population Survey (CPS), Medical Expenditure Panel Survey Household Component (MEPS), and Annual Survey of Public Employment \& Payroll (APES).

The CPS is a monthly survey of about 60,000 households conducted by the US Bureau of Labor Statistics and the Census Bureau. It provides information on a wide range of labor and income statistics; and includes data on respondents' demographic and household characteristics. We used the CPS to estimate the size of the study population, and to determine the incomes and household composition of SLG employees and retirees.

The MEPS, conducted by the Agency for Health Care Research and Quality, is a comprehensive source of information on healthcare utilization and costs. We used the household component of the MEPS to estimate healthcare expenditures for our study population.

The APES, conducted by the US Census Bureau, provides comprehensive data on government employment. The survey covers US federal, state and local civilian government employees, and permits reliable estimates of the number of full-time employees and full-time equivalents for each type of government entity. We used APES data to sort SLG employees into government entities of varying sizes, and to validate our estimates of the total number of SLG workers.

\section{B. Study Population}

We used the CPS to identify two groups: 1) current SLG employees under the age of 65 who have health insurance coverage provided by their employer; 2) SLG retirees under the age of 65 who report an SLG as their primary source of retirement income. The CPS's representative design permitted extrapolation of national estimates of the size of both groups (Figure 1 and Appendix Tables 1). We also extracted data on the number of persons under 65 in the households of each member of each group, as well as their demographic information (e.g., age and sex). Values for all CPS measures were based on averages derived from surveys conducted between 2010 and 2013. 
Results of analyses of both CPS and MEPS data were weighted to represent the civilian noninstitutionalized US population. ${ }^{6}$ We express all monetary outcomes in 2013 dollars, adjusting inflation for non-healthcare quantities (e.g., income) using the consumer price index (CPI) and adjusting healthcare costs using the medical component of the CPI.[19]

\section{Health Insurance Costs}

Estimated household healthcare costs were used as a proxy for the cost of health insurance for members of the study population, whether they obtained it through employment-based plans or on the exchanges. We predicted healthcare costs for SLG plan enrollees using MEPS data on average annual healthcare expenditures (including pharmaceuticals).

For every worker, retiree, and family member identified in the CPS analyses, we predicted an average annual healthcare expenditure, based on the individual's age, sex, and geographical region. The prediction model used an ordinary least squares regression applied to the adjusted MEPS expenditure data with restricted cubic splines for age, with knots starting at 0 and then in 15-year increments. The regression specification was a fully interacted model between the splines and indicators for sex and for region (Appendix Figure 1). Predicted expenditures were then aggregated at the household level, and expenditures on family members aged 65 years or older were excluded from the tallies.

Three main factors create some divergence between direct MEPS-based cost estimates and the true costs of health insurance to SLGs, and necessitate adjustments. Several studies have found that MEPS underestimates health care costs by up to 10\%; additionally, MEPS data does not reflect insurance company loading fees, which for SLG workforces may be in the order of $25 \%$. [20-27] Beyond this, SLG employees make some contributions (e.g. copayments, deductibles) to the costs of their health care (although these contribution levels tend to be quite low by national standards). Specifically, survey data suggests SLGs, on average, cover about $80 \%$ of the costs.[28] To account for these three factors, we adjusted our cost estimates accordingly (i.e. MEPS*1.10*1.25*0.80).

It is worth noting that the final costs we estimate exceed the premiums charged for silver plans in every state; they are closer to the cost of gold plans (Appendix Table 2).

\section{Ledger Losses to SLGs from Divestment}

\section{Penalties}

The penalty regime prescribed under the ACA fines firms that do not offer insurance options current employees, and firms that offer options that are "unaffordable" or do not provide "minimum value". ${ }^{7}$ However, there are two necessary conditions for penalty imposition: the employer must have more than 50 full-time equivalent workers, and at least one employee must

\footnotetext{
${ }^{6}$ The chief sources of uncertainty in our estimates are the estimated sizes of the study population and the precision of the predictions of the expected individual healthcare costs. The consistency of the estimated size of our study population with counts from the APES provides confidence about the precision of this estimate, at least in relation to current SLG employees. The largescale, national representativeness of MEPS permits robust healthcare cost predictions.

7 "Unaffordability" is defined as premiums that exceed 9.5\% of an employee's household income. "Minimum value" is defined as covering at least $60 \%$ of the total allowed costs of benefits expected to be incurred under the plan.
} 
have purchased a policy on the exchange and attracted a subsidy or cost-sharing. Our analysis had to account for how often these conditions were met.

Because the CPS does not identify specific SLGs, we could not directly link the profiles of individuals in our study population to characteristics of their SLGs, such as workforce size (although 2011 APES data showed that $>99 \%$ of SLG employees worked in entities with more than 30 full-time equivalent employees). We therefore made a conservative pair of assumptions: all SLGs had enough employees to expose them to penalties, and all SLGs would have at least one employee who qualified for exchange subsidies or cost-sharing. Hence, for the scenario in which SLGs cease to offer coverage entirely, we set the penalty at \$2,000 per full-time employee above the first 30 full-time employees. For scenarios in which SLGs selectively shift employees away from employment-based options, we set the penalty at $\$ 3,000$ per shifted employee eligible for a federal subsidy and/or cost-sharing. We chose the $\$ 3,000$ formulation over the $\$ 2,000$ one because, for most SLGs, it is likely to produce the lesser total penalty. Finally, we used APES data to compute the per-capita penalties according to size of SLGs' full-time workforce (Appendix Table 3).

One important caveat to the penalty calculations outlined above is that the "lesser penalty" provisions are designed to apply in situations in which the employer has offered health insurance to all full-time employees. This bears upon the question of what firms may do to selectively divest. Stripping a subset of employees of any opportunity to purchase employment-based policies would immediately trigger the $\$ 2,000$ version of the penalty; it may also be illegal. ${ }^{8}$ For these reasons, selective shifting strategies are likely to be most advantageous if they are pursued through inducements that preserve employees' voluntary choices about where to purchase their health insurance. We assume such inducements, coupled with the income supplements described below, could drive shifts away from employment-based coverage options. However, our calculations do not consider the costs of such inducements.

\section{Income Supplements}

To calculate the size of the income supplements SLGs would have to pay to make employees "whole" for premium costs they incurred in purchasing coverage on the exchange, we computed the SLG employer share (80\%) of each household's expected healthcare costs minus any subsidies and cost-sharing it would attract.

It was also necessary to consider that such income supplements may alter the tax position of SLG employees. One change is virtually certain; two others are possible. First, by increasing an employee's gross income, the supplements would increase the employee's total tax liability. Second, the additional income may bump an employee into a higher marginal tax bracket. Finally, the supplements may affect the tax deductibility of premium payments. Non-selfemployed workers may deduct premium payments in excess of $10 \%$ of their adjusted gross income (AGI). Hence, increases to AGI caused by the income supplements may reduce or eliminate the tax-deductible premiums.

Our estimates of the appropriate level of income supplementation for each SLG employee were adjusted for these three potential tax effects to ensure the supplements left employees "whole"

\footnotetext{
${ }^{8}$ See discussion of potential legal barriers below.
} 
(Appendix Sections 6-7). We did not adjust income supplements to SLG retirees for tax effects because retirees already pay tax on those benefits.

\section{E. Ledger Gains to SLGs from Divestment}

\section{Medicaid Coverage}

To calculate household income as a percentage of the FPL, we used CPS data on total household income for SLG employees and under-65-retirees. For households with income below 138\% FPL, we assumed household members younger than 65 years would be eligible for Medicaid, thereby shifting costs from SLGs to those programs. In our base calculation this assumption applied only to the 26 states (including the District of Columbia) implementing Medicaid expansions as of January 28, 2014 as the federal government covers the overwhelming majority of the healthcare costs for individuals newly enrolled in states expanding Medicaid (Appendix Table 4).[29] In a secondary calculation, we examined the implication for financial incentives to divest if one assumed that all states would expand Medicaid.

Both assumptions are imperfect. Income eligibility thresholds for Medicaid programs vary across states and population subgroups (children, pregnant women, etc.).[30] In certain states and for certain subgroups, income eligibility thresholds are above 138\% FPL. The main consequence of not accounting for these nuances is that we counted fewer individuals in the study population as Medicaid eligible than was truly the case, which, all else equal, would tend to bias downward our estimates of any SLG savings from divestment. Finally, even in states that continue to bear a substantial share of Medicaid costs (because they have not expanded Medicaid) and hence may not find it financially advantageous to shift workers on to this source of coverage, local governments are not so constrained. Thus, we were conservative in assuming that local governments would behave like their state counterparts. ${ }^{9}$.

\section{Subsidies and Cost-Sharing for Individual Purchasers}

For households with incomes between 138-400\% FPL, we followed ACA rules for determining the amounts of subsidies and cost-sharing (Appendix Section 5).[31] For households with income above $400 \%$ FPL, we assumed no subsidies or cost-sharing.

Household income determines the levels of both subsidies and cost-sharing. Therefore, if SLGs provide income supplements to offset any additional costs employees and retirees face in purchasing insurance on the exchange, this may in turn affect eligibility for subsidies and costsharing. The relationship between these variables is dynamic. As income supplements boost total household income, subsidies and cost-sharing drop, necessitating larger supplements to achieve status quo. Tax effects are an additional variable in this dynamic equation. We solved for the stable levels of subsidies, cost-sharing, and income supplements using a two-step, fixed point method (Appendix Section 7).

\section{Eligibility for Exchange Subsidies and Cost-Sharing}

The ACA explicitly authorized subsidies for policies purchased through state-operated exchanges, but included no such explicit authorization for purchases on federally operated

\footnotetext{
${ }^{9}$ Admittedly, this assumption was a necessity because the CPS data did not permit separation of households with state government employees from those with local government employees.
} 
exchanges. ${ }^{10}$ On July 22 2014, the US Court of Appeals for the District of Columbia struck down an IRS ruling that had declared subsidies were available on federal exchanges.[32] Hours later the Fourth Circuit Court of Appeals in another decision upheld the IRS's interpretation, ruling that the statutory language was ambiguous.[33] In November 2014, the US Supreme Court granted certiorari in King, and a decision is expected in mid-2015.

What effects would success for the plaintiffs-appellants in King have on our estimates? There are actually four different types of exchanges: (1) state-based marketplaces; (2) federallysupported state-based marketplaces (in state exchanges use the federal information technology platform); (3) state-partnership marketplaces (in which states provide consumer assistance but the federal government does the rest); and (4) federally-facilitated marketplaces. A win for the plaintiffs-appellants in King would likely invalidate subsidies for federally-facilitated exchanges and probably also invalidate them for partnership exchanges, but projecting implications beyond that is difficult. We performed a sub-analysis that assessed SLG employer savings in the event that subsidies became available only on state-based-marketplaces $(n=14)$ and federally-support state-based marketplaces $(\mathrm{n}=3)^{11}$

\section{RESULTS}

\section{A. Status Quo}

SLGs in the US employ approximately 12 million workers and have 1.5 million retirees under the age of 65 (Figure 1). The average household size is 3.5 persons for workers and 2.5 for retirees. Thus, SLGs provide health insurance benefits to up to 45 million individuals.

We estimate that the study population - SLG employees, SLG retirees under 65 years of age, and the families of both groups - will incur approximately \$1.8 trillion in healthcare costs over the next 10 years (Appendix Table 6). This total consists of \$1.59 trillion for employees and their families and $\$ 250$ billion for retirees and their families. For context, this equates to $6 \%$ of the total cost of the US healthcare system over the decade. [35] [35]

\section{B. Household Income and Eligibility for Financial Assistance}

Thirty nine percent of the study population had household incomes low enough to qualify for subsidies and/or cost-sharing on the health insurance exchanges (Figure 2 and Appendix Table 6). Nationally, 40\% of SLG employees had household incomes in the 138-400\% FPL range and 33\% of retirees did. An additional 3\% of households met the ACA's Medicaid income eligibility threshold. There was substantial variation across states in the proportion of SLG employees and retirees whose household incomes fell within these bands (Appendix Table 7).

\section{Full Divestment}

\footnotetext{
${ }^{10}$ The ACA provides for establishment of state exchanges under $\$ 1311$. In the event a state does not establish an exchange, $\S 1321$ authorizes the federal government to do so. At issue in Halbig and King were the final regulations the IRS released on section 36B of the Internal Revenue Code, which extended the ACA's premium assistance program to exchanges established under both $\S 1311$ and $\S 1321$.

11 The status of states exchanges came from the most recent version of a tracking report published by the Kaiser Family Foundation with the list reproduced in Appendix Table 5. [3] State Health Insurance Marketplace Types, 2015. 2015 Available from: http://kff.org/health-reform/state-indicator/state-health-insurance-marketplace-types/
} 
Exiting employment-based health insurance altogether would be a more expensive proposition than the status quo for SLGs in almost all states and the District of Columbia (Appendix Tables 8-10). This result is primarily driven by the size of the employer penalties. But penalties aside, in 29 states, the size the income supplements required to leave employees and retirees no worse off outstrip the combined savings reaped from subsidies and Medicaid displacement. A recalculation that assumed all states proceeded with Medicaid expansions (as opposed to the 26 jurisdictions that currently are) did not eliminate the net losses associated with full divestment (Appendix Tables 11-13).

\section{Selective Divestment}

An alternative strategy for SLGs is to encourage particular subgroups of beneficiaries to seek coverage elsewhere. There are many possibilities for construction of the subgroups. We focused on the cost implications of shifting two clearly defined subgroups: (1) under-65-retirees, and (2) employees whose household income levels make them eligible for either Medicaid coverage or subsidies on the exchanges.

\section{Retirees}

It should not be surprising that several cities and municipalities have already signaled interest in shifting under-65 retirees to alternative sources of coverage. Several elements of the cost equation suggest it may be particularly advantageous to do so. In particular, employer penalties do not apply and the tax effects of income supplementation are minimal or nil.

We estimated that shifting retirees and their households to health insurance purchased on the exchanges could save SLGs more than \$18 billion over 10 years (Table 1 and Appendix Table 9). Every state would save. Approximately $80 \%$ of these savings stem from subsidies and costsharing; the rest come from Medicaid displacement of SLG coverage. Total savings rise to more than $\$ 21$ billion over 10 years under the assumption that all states undertake Medicaid expansions (Table 1 and Appendix Table 12).

\section{Medicaid- or Subsidy-Eligible Employees}

Because current employees account for most of SLGs' healthcare costs, the savings attained by any selective shifts of them are potentially much larger than those attainable from shifting retirees. The cost equation employed in our model lays bare which groups of employees will provide the most lucrative returns to selective divestment: employees who are Medicaid eligible, or who attract substantial subsidies and cost-sharing on the exchanges.

We estimate that shifting this subgroup of workers from employment-based coverage would save SLGs more than $\$ 100$ billion over 10 years (Table 1 and Appendix Tables 14). Despite paying $\$ 88$ billion in penalties and almost $\$ 30$ billion in income supplements over the decade, the \$197 billion gained in subsidies and cost-sharing and the $\$ 21$ billion absorbed by federal support of Medicaid expansions, overwhelm these losses. Total savings would increase to more than \$130 billion over 10 years if all states undertook Medicaid expansions (Table 1 and Appendix Table 15).

\section{E. Divestment in a World Where Only State-Based Exchanges May Provide Subsidies}


In states where subsidies (and the associated penalties) are unavailable, divestment will always look financially unattractive to SLGs, relative to the status quo. In the 17 states that have implemented exchanges, full divestment was less financially attractive than selective divestment. Table 2 shows that shifting all under-65 retirees to alternative forms of health insurance coverage could save SLGs more nearly \$8 billion over 10 years. Selective divestment from coverage for Medicaid- or Subsidy-Eligible employees in these states could save SLGs more than $\$ 42$ billion over 10 years.

\section{DISCUSSION}

\section{A. Overview of Findings}

This study estimated that completely exiting the direct provision of employment-based health insurance would not save SLGs money. However, selective divestment to take advantage of coverage options introduced by the ACA could save SLGs nearly \$119 billion over the next 10 years (or \$150 billion if all states implemented Medicaid expansions). Savings of this magnitude could substantially improve the weak financial position of many SLGs.

The vast majority of the savings we have identified would come from costs shifted to the federal government. Hence, if SLGs were to follow en masse the selective divestment strategies we have outlined, it could add more than $10 \%$ to the projected costs of ACA reforms.[36] For the kinds of political and practical reasons mentioned earlier, divestment en masse seems unlikely, at least in relation to current employees. Therefore the SLG savings and additional costs to the federal government we have estimated are best interpreted as upper bounds.

\section{B. Assumptions and Limitations}

Our analysis makes a number of simplifying assumptions. One is that removing any differences in the costs of health insurance will make SLG employees indifferent to the prospect of obtaining insurance elsewhere. This does not necessarily follow. Plans purchased on the exchange may have smaller networks and may require SLG employees and retirees to switch from physicians they know and like. Further, employees who shift to Medicaid coverage may have trouble finding willing providers.[37, 38]

It is possible that an accumulation of such non-monetary factors may prompt some beneficiaries to respond strategically — for example, by seeking employment elsewhere, shifting to coverage available through a spouse's policy, even dropping coverage and pocketing the income supplement. The theoretical effects of such behavioral responses on our estimates are unclear; they run in both directions and disentangling and quantifying them requires further research.

Employers, too, may engage in strategic behavior. Salary adjustments or hiring practices may be used to alter the mix of employees eligible for the federally-subsidized coverage. SLGs may also seek to minimize their exposure to penalties by reducing the size of their full-time or full-time equivalent workforce, turning to part-time workers, outsourcing, and other measures. However, employers' latitude to take such action is constrained. Unions would vigorously resist any such large-scale changes. Moreover, since SLGs tend to be relatively large employers, workforce 
changes could reduce the size of penalties based on employee multipliers, but it would be infeasible for most to shrink below the thresholds that trigger mandates and penalties.

Another simplifying assumption is that all SLGs currently offer coverage to their employees and retirees, all of whom take it up. This is not the case. The Kaiser Family Foundation's 2013 health insurance survey estimated that, although virtually every SLG had some offering, 80\% of workers were eligible, of whom 91\% took up insurance, resulting in a coverage proportion of $73 \%$.[5, 39] Uptake rates for eligible employees are high chiefly because SLG plans tend to be generous. The number of under-65-retirees who receive health insurance benefits from SLGs is more difficult to estimate. As a proxy, we used the proportion who, according to the CPS, received SLG retirement benefits. Overestimating the number of employees and retirees to whom insurance is currently provided would result in overestimates of the size of current obligations and total savings attainable, but it should have little effect on the size of per-person savings.

It should also be acknowledged that, while divestment incentives may confront all employers, SLGs are distinctive in a number ways that may limit the direct generalizability of our analysis to non-public sector firms. Perhaps the most salient of these distinctions is that shifts of beneficiaries to Medicaid are not costless for state governments because they share the costs of this program with the federal government. For states that have expanded Medicaid under the ACA, the share is small ( $0 \%$ through 2017 , and $10 \%$ thereafter). For states that have not, the state contribution to Medicaid averages $\sim 45 \%$ but varies considerable across states. Such costsharing implications may alter the financial incentives state governments face to divest in unique ways.

Our estimates of SLG financial incentives over a 10-year time horizon do not take account of other factors that may change over this period and affect the financial incentives to divest that SLGs face. The main time-varying determinants of the magnitude of incentives are: (1) Pace of medical cost growth; (2) SLG workforce size; (3) Demography of the SLG workforce; (4) Overall health/pace of the economy; and (5) Political/legal shifts that may change the ACA at the national level or the preferences of particular State and Local Governments. In principal, it would be possible using our approach or dynamic microsimulations to incorporate trends in (1) through (3) based the historical experience as represented by datasets like MEPS and CPS. Even for these, we note that SLG worker tenure and retirement prior to age 65 (i.e., (2) and (3)) may depend in complex ways on (1) and its interaction with SLG policies in regard to health insurance provision. The latter two determinants ((4) and (5)) do not lend themselves as readily to modeling based on historical data. Hence, we elected not to incorporate trends into our estimates but instead to properly contextualize them.

\section{Legal Issues}

Our analyses also rest on several legal assumptions that warrant closer scrutiny and justification. An in-depth analysis of the legal issues raised by divestment from employment-based insurance under the ACA is beyond the scope of this paper. We merely describe three areas of legal uncertainty that may arise.

\section{Challenges to Key ACA Provisions}


One assumption the estimates of our main analysis make is that, with the exception of the Medicaid expansions (which the US Supreme Court has already ruled cannot be forced upon states [40]), the reforms introduced by the ACA will survive more-or-less intact. A bevy of challenges to various provisions of the ACA continue to move through state and federal courts across the country.[41] If successful, some of these challenges could alter the structure of ACA reforms in ways that would significantly affect our calculations.

We tested the robustness of our estimates to the effects of the line of attack to which the ACA reforms appear most vulnerable today-namely, elimination of subsidies and penalties in states that have not established their own exchanges. This sub-analysis shows that elimination of subsidies on the federal exchanges would have dramatic effects: 27 states currently have them (with a further 7 states operate joint state-federal "partnership" exchanges), and divestment becomes a uniformly losing proposition in those states.

There are other types of challenges whose effects on our estimates we did not explore. For example, we assumed that SLGs, like private sector employers, are liable to pay the ACA penalties for failing to provide insurance, or for offering "unaffordable” insurance. Several legal challenges currently on foot argue that forcing SLGs to pay penalties violates the $10^{\text {th }}$ Amendment of the U.S. Constitution.[42] If tax penalties against SLGs were found to be unconstitutional, and subsidies survived the King challenge, our calculations would underestimate potential savings from divestment.

\section{Legality of Selective Divestment}

We assumed the divestment strategies we analyzed would be lawful. For some SLGs, however, divestment may breach contracts in force with public sector unions or other employee groups. We could not observe, and so did not consider, the constraints such private arrangements may place on SLGs' discretion to divestment.

Private agreements aside, it is difficult to imagine a scenario in which full divestment would be considered unlawful. The employer mandate is a "play or pay" rule, not a true mandate. Opting completely out of health benefits offerings is therefore permitted, provided the employer pays any applicable penalties. Similarly, divestment focused on under-65 retirees would also lawful; SLGs are not bound, at least not under federal law, to provide health benefits to retirees. A selective divestment strategy aimed at employees eligible for Medicaid or subsidies on the exchange presents a somewhat more difficult case.

The two main federal laws that govern employer-based health insurance are the Employee Retirement Income Security Act of 1974 (ERISA) and the Internal Revenue Code of 1986 (IRC). ERISA also incorporates the non-discrimination provisions of the Health Insurance Portability and Accountability Act, which prohibit group health plans from structuring eligibility, benefits, or premiums in ways that discriminate among employees on the basis of health-related factors. In addition, the ACA itself includes a number of provisions that limit the ability of employers to undertake "risk based" classifications of employees when providing health benefits (although nearly all of these restrictions overlap with ones that were already in place pre-ACA under ERISA and the IRC [43]). 
Would any of these federal laws bar selective divestment? Firm answers to that question require a more comprehensive legal analysis than we have the space (or expertise) to undertake here. However, several observations are relevant.

Although ERISA regulates many aspects of plan administration, and certain of its provisions may bear upon employers’ latitude to divest, it does not apply to SLGs.

The primary focus of the HIPAA and ACA non-discrimination rules is disparate treatment of employees who are sick or costly. That is not an accurate characterization of the selective divestment strategy we have considered for two reasons. First, in the scenario we analyzed, employees eligible for cost-sharing are incentivized to purchase insurance elsewhere but they are not excluded from employment-based coverage. Second, the defining characteristic of the subgroup we constructed was the availability of external cost-sharing, not bad insurance risk. While it may be tempting to assume the two overlap, our data suggest this is not the case: the average health care costs we estimate for SLG employees eligible for Medicaid and subsidies appear to quite similar, on average, than the costs estimated for employees who are not (Appendix Table 15). Subsidy-eligible employees tend to be younger, and this age effect may counter-balance any association between lower income and ill health.

The IRC prohibits self-insured health plans from discriminating in favor of "highly-compensated individuals" with respect to eligibility, contributions, and benefits. ${ }^{12}$ The ACA extends this prohibition to sponsors of group health plans (other than self-insured plans). ${ }^{13}$ At first glance, these rules come much closer than risk classification prohibitions do to a selective divestment strategy centered on subsidy-eligible employees. However, the match is still doubtful. ${ }^{14}$ "Highly compensated individuals" are a defined group (a top-five paid officer, a more-than-10 percent shareholder, and 25 percent of employees with the highest salaries), which is unlikely to align well with the profile of SLG employees not incentivized to switch plans. More importantly, SLGs' use of incentive structures and sponsorship of benefits obtained from other sources seems tangential to the kind of "rules" and "eligibility" exclusions addressed by the IRC and ACA nondiscrimination provisions.

\section{Legality of Income Supplements}

The IRS, joined by the Department of Labor and the Department of Health and Human Services, recently issued a guidance clarifying that, under the ACA, payments employers make to employees for purposes of covering the costs of health insurance purchased on the exchanges will not enjoy preferential tax treatment.[44] Under section 125 of the IRC, compensation funneled through “employer payment plans” qualified for the same tax exemptions as other kinds of employer contributions to the costs of employee health insurance. However, regulators have moved to block this under the ACA, in part to blunt incentives for employers to send employees elsewhere.

12, Internal Revenue Code, §105(h).

13. ACA, §2716. At the date of writing, this provision is not yet active. In Notice 2011-1, the IRS delayed the effective date of this provision until guidance on how the section applies in the fully insured context is issued, and none has been.

14. In addition to the questions of applicability outlined in this section, the applicability of these nondiscrimination provisions to SLGs is uncertain. Formerly, SLGs were exempted from the rule (see Taxpayer Relief Act of 1997 (P.L. 105-34), §1505),

although there is no exception mentioned in ACA provision. Thus, technically, HHS appears to have the authority to enforce the nondiscrimination rules against insured non-federal governmental plans, but it is not yet clear whether it will do so. 
The ruling does not directly affect our calculations because we assumed income supplements would be paid with after-tax monies. It does, however, highlight a factor that we did not take into account. If SLGs' contributions to the costs of health insurance are tax exempt in the status quo, but the income supplements incur payroll and other taxes (e.g., the Federal Insurance Contributions Act (FICA) tax), this difference should be included in the tally of ledger losses. To the extent we did not do this, we may have overestimated savings. ${ }^{15}$

\section{CONCLUSION}

Employment-based health insurance is a central pillar of the U.S. healthcare system. Its existence has long framed options for reform. Although the ACA sought to expand coverage by building around and strengthening employment-based insurance, the changes it introduces to the sources and financing of coverage have the potential to reset the playing field entirely. How employers will respond remains to be seen.

This study considered possible reactions by one large employer group with strong motives to reduce the burden of health insurance costs. We found that SLGs may save nearly $\$ 119$ billion over the next 10 years by shifting under-65-retirees and segments of their workforce to comparable plans on the exchanges and Medicaid programs. Such savings would be gained at the expense of the federal government.

SLGs garner no special treatment under the ACA. The cost advantages projected for them may apply to greater or lesser extents to other employers, depending on the demographic, income and healthcare utilization profiles of workers in those firms. General divestment is not barred by state or federal law, but SLGs may have contracts in force with employees that limit their ability to pursue this strategy. Selective divestment does not face clear legal barriers either, although this depends on how subgroups of interest are constructed; certain forms of selectivity, such as targeting employees with the highest health care expenses - a strategy we do not consider (or in any way endorse) — would probably violate federal nondiscrimination protections.

The federal government could probably stem any rush toward divestment by changing key rules, such as penalty levels and eligibility for subsidies and cost-sharing. But until that happens, divestment is a strategic option that diligent business leaders may find difficult to ignore.

\footnotetext{
${ }^{15}$ In the selective divestment scenario, the income supplement provided by the SLGs would increase the size of the FICA tax owed. As the goal of selective divestment is not to make the employee worse off, the SLG might cover both the employer and employee portions - roughly 15\%. However, as FICA is deducted prior to computing total income for the purpose of income taxes, the income tax supplement from the SLG would be lowered by roughly the marginal tax rate ( 25\% in our group). Hence our estimates of savings may be $\sim 11 \%$ too high depending on how SLGs choose to compensate employees for these amounts. It is not entirely clear that compensation is necessary as Social Security and Medicare could be viewed as benefits that employees receive later in life and hence their benefit offsets greater withholding now.
} 


\section{REFERENCES}

[1] Rodden JA. Hamilton's Paradox: The Promise and Peril of Fiscal Federalism. European Journal of Political Economy. 2006.

[2] Federalism and the Welfare State : New World and European Experiences: Cambridge University Press 2006.

[3] Cutler DM, Gruber J. Does Public Insurance Crowd out Private Insurance? The Quarterly Journal of Economics. 1996; 111(2):391-430.

[4] Oliff P, Mai C, Palacios V. States Continue To Feel Recession's Impact. Washington, DC: Center on Budget and Policy Priorities; 2012.

[5] Employer Health Benefits 2013, Annual Survey: The Kaiser Family Foundation \& Health Research and Education Trust; 2013.

[6] The Widening Gap Update: The Pew Center on the United States; June 2012.

[7] State and Local Government Retiree Health Benefits: Liabilities Are Largely Unfunded, but Some Governments Are Taking Action. Washington, DC: Government Accountability Office; 2009.

[8] Summary of Statement No. 45: Accounting and Financial Reporting By Employers For Postemployment Benefits Other Than Pensions. June 2004 Available from: http://www.gasb.org/st/summary/gstsm45.html

[9] State, Local Government Spending on Health Care Grew Faster Than National Rate in 2012: The Pew Charitable Trusts; Jan 2014.

[10] The Patient Protection and Affordable Care Act. U.S.A2010:119.

[11] Davey M, Goodnough A. Detroit Looks to Health Law to Ease Costs. The New York Times. July 2013.

[12] Sheboygan County Retirees may be shifted to ObamaCare. Milwaukee Journal Sentinel. April 2013.

[13] U.S cities looking to shed retired employees' healthcare costs. United Press International. July 2013.

[14] Memo to Stockton Retiree receiving Retiree Medical benefits. April 2013 Available from: http://www.stocktongov.com/files/Retiree_Healthcare_Option_Letter_April_1_2013.pdf [15] Buchmueller T, Carey C, Levy HG. Will employers drop health insurance coverage because of the Affordable Care Act? Health Aff (Millwood). 2013; 32(9):1522-30.

[16] Hall M, Monahan A. Paying for Individual Health Insurance through Tax-sheltered Cafeteria Plans. Inquiry. 2010; 47(3):252-61.

[17] Federal, State and Local Governments : Quick Reference Guide for Public Employers: Internal Revenue Service; February 2013.

[18] Publication 502 : Medical and Dental Expenses. Available from: http://www.irs.gov/publications/p502/ar02.html

[19] Consumer Price Index. 2014 Available from: http://www.bls.gov/cpi/

[20] Meara E, White C, Cutler DM. Trends In Medical Spending By Age, 1963-2000. Health Affairs. 2004; 23(4):176-83.

[21] Economic costs of diabetes in the U.S. in 2012. Diabetes Care. 2013; 36(4):1033-46.

[22] Aizcorbe A, Liebman E, Pack S, Cutler DM, Chernew ME, Rosen AB. Measuring health care costs of individuals with employer-sponsored health insurance in the U.S.: A comparison of survey and claims data. Statistical Journal of the IAOS: Journal of the International Association for Official Statistics. 2012; 28(1):43-51. 
[23] Improving Health Cost Projections for the Medicare Population: Summary of a Workshop: National Research Council Committee on National Statistics; 2010.

[24] Bernard D, Cowan C, Selden T, Cai L, Catlin A, Heffler S. Reconciling medical expenditure estimates from the MEPS and NHEA, 2007. . (2159-0354 (Electronic)).

[25] Sing M, Banthin J, Selden T, Cowan C, Keehan S. Reconciling medical expenditure estimates from the MEPS and NHEA, 2002. (0195-8631 (Print)).

[26] Selden TM, Sing M. Aligning the Medical Expenditure Panel Survey to Aggregate U.S. Benchmarks. . Agency for Healthcare Research and Quality. 2008; (Working Paper No. 08006). [27] Karaca-Mandic P, Abraham JM, Phelps CE. How do health insurance loading fees vary by group size?: implications for Healthcare reform. Int J Health Care Finance Econ. 2011; 11(3):181-207.

[28] The Pew Charitable Trusts and the MacArthur Foundation. State Employee Health Plan Spending: An examination of premiums, cost drivers, and policy approaches. 2014.

[29] State Health Facts : Status of State Action on the Expansion Decision. 2014 Available from: http://kff.org/health-reform/state-indicator/state-activity-around-expanding-medicaid-underthe-affordable-care-act/

[30] State Medicaid and CHIP Income Eligibility Standards Effective January 1, 2014. Available from: http://www.medicaid.gov/AffordableCareAct/Medicaid-Moving-Forward2014/Downloads/Medicaid-and-CHIP-Eligibility-Levels-Table.pdf

[31] Austin DR, Luan A, Wang LL, Bhattacharya J. Small Increases To Employer Premiums Could Shift Millions Of People To The Exchanges And Add Billions To Federal Outlays. Health Affairs. 2013; 32(9):1531-7.

[32] Halbig v. Burwell. D.C Cir. 2014.

[33] King et al v. Burwell. US Court of Appeals, 4th Circuit 2014.

[34] State Health Insurance Marketplace Types, 2015. 2015 Available from:

http://kff.org/health-reform/state-indicator/state-health-insurance-marketplace-types/

[35] National Health Expenditures 2012 Highlights. Available from:

http://www.cms.gov/Research-Statistics-Data-and-Systems/Statistics-Trends-and-

Reports/NationalHealthExpendData/downloads/highlights.pdf

[36] Elmendorf DW. Letter to U.S CongressMarch 2010.

[37] Decker SL. In 2011 Nearly One-Third Of Physicians Said They Would Not Accept New Medicaid Patients, But Rising Fees May Help. Health Affairs. 2012; 31(8):1673-9.

[38] Goodnough A. Medicaid Growth Could Aggravate Doctor Shortage. The New York

Times. November 2013.

[39] State Employee Health Benefits. December 2013 Available from:

http://www.ncsl.org/research/health/state-employee-health-benefits-ncsl.aspx

[40] Nat'l Fed'n of Indep. Bus. v. Sebelius. 2012.

[41] Gostin LO, Jacobson PD, Studdert DM. Law and Health System: St Paul, MN:

Foundation Press 2014.

[42] State of Indiana et al v. Internal Revenue Service. US District Court, Southern District of Indiana, Indianapolis Division 2013.

[43] Monahan A, Schwarcz D. Will Employers Undermine Health Care Reform by Dumping Sick Employees. Virginia Law Review. 2011; 97:125-97.

[44] Herrera CN, Gaynor M, Newman D, Town RJ, Parente ST. Trends underlying employersponsored health insurance growth for Americans younger than age sixty-five. Health Aff (Millwood). 2013; 32(10):1715-22. 
Table 1. Estimated savings to state and local governments from selective divestment strategies $\mathbf{( \$ 1 , 0 0 0 , 0 0 0 s )}$

\begin{tabular}{|c|c|c|c|c|}
\hline \multirow[b]{2}{*}{ State } & \multicolumn{2}{|c|}{ Shifting only under-65-retirees } & \multicolumn{2}{|c|}{$\begin{array}{c}\text { Shifting only employees eligible for subsidies or } \\
\text { Medicaid }\end{array}$} \\
\hline & $\begin{array}{l}26 \text { states expand } \\
\text { Medicaid } \\
\text { (1a) }\end{array}$ & $\begin{array}{l}\text { All states expand } \\
\text { Medicaid } \\
* * \\
\text { (1b) }\end{array}$ & $\begin{array}{c}26 \text { states expand } \\
\text { Medicaid } \\
\text { (2a) }\end{array}$ & $\begin{array}{l}\text { All states expand } \\
\text { Medicaid } \\
* * \\
(2 b)\end{array}$ \\
\hline Alabama & 46 & 60 & 268 & 412 \\
\hline Alaska & 11 & 14 & 13 & 33 \\
\hline Arizona & 75 & & 367 & \\
\hline Arkansas & 39 & & 199 & \\
\hline California & 202 & & 1,389 & \\
\hline Colorado & 38 & & 187 & \\
\hline Connecticut & 12 & & 110 & \\
\hline Delaware & 7 & & 27 & \\
\hline District Of Columbia & 3 & & 9 & \\
\hline Florida & 133 & 154 & 482 & 746 \\
\hline Georgia & 68 & 75 & 360 & 702 \\
\hline Hawaii & 34 & & 64 & \\
\hline Idaho & 12 & 12 & 79 & 107 \\
\hline Illinois & 23 & & 306 & \\
\hline Indiana & 35 & 46 & 217 & 294 \\
\hline Iowa & 15 & & 121 & \\
\hline Kansas & 15 & 19 & 82 & 229 \\
\hline Kentucky & 33 & & 293 & \\
\hline Louisiana & 42 & 113 & 210 & 362 \\
\hline Maine & 11 & 15 & 33 & 41 \\
\hline Maryland & 38 & & 216 & \\
\hline Massachusetts & 33 & & 182 & \\
\hline Michigan & 48 & & 252 & \\
\hline Minnesota & 21 & & 87 & \\
\hline Mississippi & 33 & 43 & 173 & 341 \\
\hline Missouri & 24 & 42 & 180 & 221 \\
\hline Montana & 10 & 15 & 43 & 59 \\
\hline Nebraska & 7 & 13 & 52 & 71 \\
\hline Nevada & 11 & & 44 & \\
\hline New Hampshire & 4 & 12 & 17 & 28 \\
\hline New Jersey & 51 & & 224 & \\
\hline New Mexico & 40 & & 163 & \\
\hline New York & 215 & & 987 & \\
\hline North Carolina & 91 & 99 & 457 & 647 \\
\hline North Dakota & 2 & & 19 & \\
\hline Ohio & 100 & & 452 & \\
\hline Oklahoma & 15 & 35 & 133 & 241 \\
\hline Oregon & 25 & & 176 & \\
\hline Pennsylvania & 86 & 114 & 161 & 227 \\
\hline Rhode Island & 8 & & 22 & \\
\hline South Carolina & 81 & 93 & 149 & 250 \\
\hline South Dakota & 5 & 5 & 17 & 29 \\
\hline Tennessee & 22 & 44 & 170 & 345 \\
\hline Texas & 137 & 161 & 833 & 1,499 \\
\hline Utah & 8 & 8 & 104 & 141 \\
\hline Vermont & 7 & & 17 & \\
\hline Virginia & 37 & 82 & 144 & 234 \\
\hline Washington & 31 & & 218 & \\
\hline West Virginia & 24 & & 136 & \\
\hline Wisconsin & 15 & 21 & 141 & 289 \\
\hline
\end{tabular}




\begin{tabular}{|l|r|r|r|r|}
\hline Wyoming & 9 & 11 & 23 & 33 \\
\hline NATIONAL & 2,095 & 2,442 & 10,804 & 13,847 \\
\hline 10 YEARS & 20,946 & 24,419 & 108,039 & 138,466 \\
\hline
\end{tabular}

* State and local government totals for these states are only positive because of savings from retirees under age 65 years. The costs of terminating all employment-based coverage options for current state and local government workers in these states due to employer penalties and increased liabilities for taxes more than offset the gains from federal subsidies and cost-sharing.

** Estimates are only shown in the "All States Medicaid Expansion” columns for states that do not currently have a Medicaid expansion planned for 2014. Under a Medicaid expansion, the estimates are different than the previous column and hence are shown.

Note: The table shows the magnitude of savings to state and local governments from divestment strategies shifting SLG workers and/or under-65 retirees onto health insurance exchanges or into federally supported Medicaid expansions under two scenarios - current Medicaid expansions or else full Medicaid expansions in all states. The results are shown by state and for the nation as a whole as well as nationally over 10 years.

Sources for this data involve authors' calculations using MEPS and CPS data collected by the US government along with data from the Kaiser Family Foundation on states' Medicaid expansion statuses. 
Table 2. Estimated savings to state and local governments from selective divestment strategies $(\mathbf{\$ 1 , 0 0 0 , 0 0 0 s )}$ in states implementing Medicaid expansions and not using federal exchanges

\begin{tabular}{|c|c|c|}
\hline & $\begin{array}{c}\text { Shifting only } \\
\text { under-65-retirees }\end{array}$ & $\begin{array}{c}\text { Shifting only } \\
\text { employees eligible } \\
\text { for subsidies or Medicaid }\end{array}$ \\
\hline State & $\begin{array}{l}26 \text { states expand } \\
\text { Medicaid }\end{array}$ & $\begin{array}{c}26 \text { states expand } \\
\text { Medicaid }\end{array}$ \\
\hline \multicolumn{3}{|l|}{ Alabama } \\
\hline \multicolumn{3}{|l|}{ Alaska } \\
\hline \multicolumn{3}{|l|}{ Arizona } \\
\hline \multicolumn{3}{|l|}{ Arkansas } \\
\hline California & 202 & 1,389 \\
\hline Colorado & 38 & 187 \\
\hline Connecticut & 12 & 110 \\
\hline \multicolumn{3}{|l|}{ Delaware } \\
\hline $\begin{array}{l}\text { District Of } \\
\text { Columbia }\end{array}$ & 3 & 9 \\
\hline \multicolumn{3}{|l|}{ Florida } \\
\hline \multicolumn{3}{|l|}{ Georgia } \\
\hline Hawaii & 34 & 64 \\
\hline Idaho & 12 & 79 \\
\hline \multicolumn{3}{|l|}{ Illinois } \\
\hline \multicolumn{3}{|l|}{ Indiana } \\
\hline \multicolumn{3}{|l|}{ Iowa } \\
\hline \multicolumn{3}{|l|}{ Kansas } \\
\hline Kentucky & 33 & 293 \\
\hline \multicolumn{3}{|l|}{ Louisiana } \\
\hline \multicolumn{3}{|l|}{ Maine } \\
\hline Maryland & 38 & 216 \\
\hline Massachusetts & 33 & 182 \\
\hline \multicolumn{3}{|l|}{ Michigan } \\
\hline Minnesota & 21 & 87 \\
\hline \multicolumn{3}{|l|}{ Mississippi } \\
\hline \multicolumn{3}{|l|}{ Missouri } \\
\hline \multicolumn{3}{|l|}{ Montana } \\
\hline \multicolumn{3}{|l|}{ Nebraska } \\
\hline Nevada & 11 & 44 \\
\hline \multicolumn{3}{|l|}{ New Hampshire } \\
\hline \multicolumn{3}{|l|}{ New Jersey } \\
\hline New Mexico & 40 & 163 \\
\hline New York & 215 & 987 \\
\hline \multicolumn{3}{|l|}{ North Carolina } \\
\hline \multicolumn{3}{|l|}{ North Dakota } \\
\hline \multicolumn{3}{|l|}{ Ohio } \\
\hline Oklahoma & & \\
\hline Oregon & 25 & 176 \\
\hline Pennsylvania & & \\
\hline Rhode Island & 8 & 22 \\
\hline South Carolina & & \\
\hline South Dakota & & \\
\hline Tennessee & & \\
\hline Texas & & \\
\hline Utah & & \\
\hline Vermont & 7 & 17 \\
\hline Virginia & & \\
\hline
\end{tabular}




\begin{tabular}{|l|r|r|}
\hline Washington & 31 & 218 \\
\hline West Virginia & & \\
\hline Wisconsin & & \\
\hline Wyoming & & 4,243 \\
\hline NATIONAL & 764 & 42,425 \\
\hline 10 YEARS & 7,643 & \\
\hline
\end{tabular}

Note: The table shows the magnitude of savings to state and local governments from divestment strategies shifting SLG workers and/or under-65 retirees onto health insurance exchanges or into federally supported Medicaid expansions. The scenario shown in the table involves only states that have their own exchanges - the type not at risk if Supreme Court decisions invalidate subsidies and cost-sharing for federally administered exchanges. The results are shown by state and for the nation as a whole as well as nationally over 10 years. Sources for this data involve authors' calculations using MEPS and CPS data collected by the US government along with data from the Kaiser Family Foundation on the type of exchanges operating in each state along with their Medicaid expansion status. 
Figure 1: State and local governments workers and retirees below 65 years of age as \% of state population age $18-65$ years

\section{A) State and Local Government Employees}
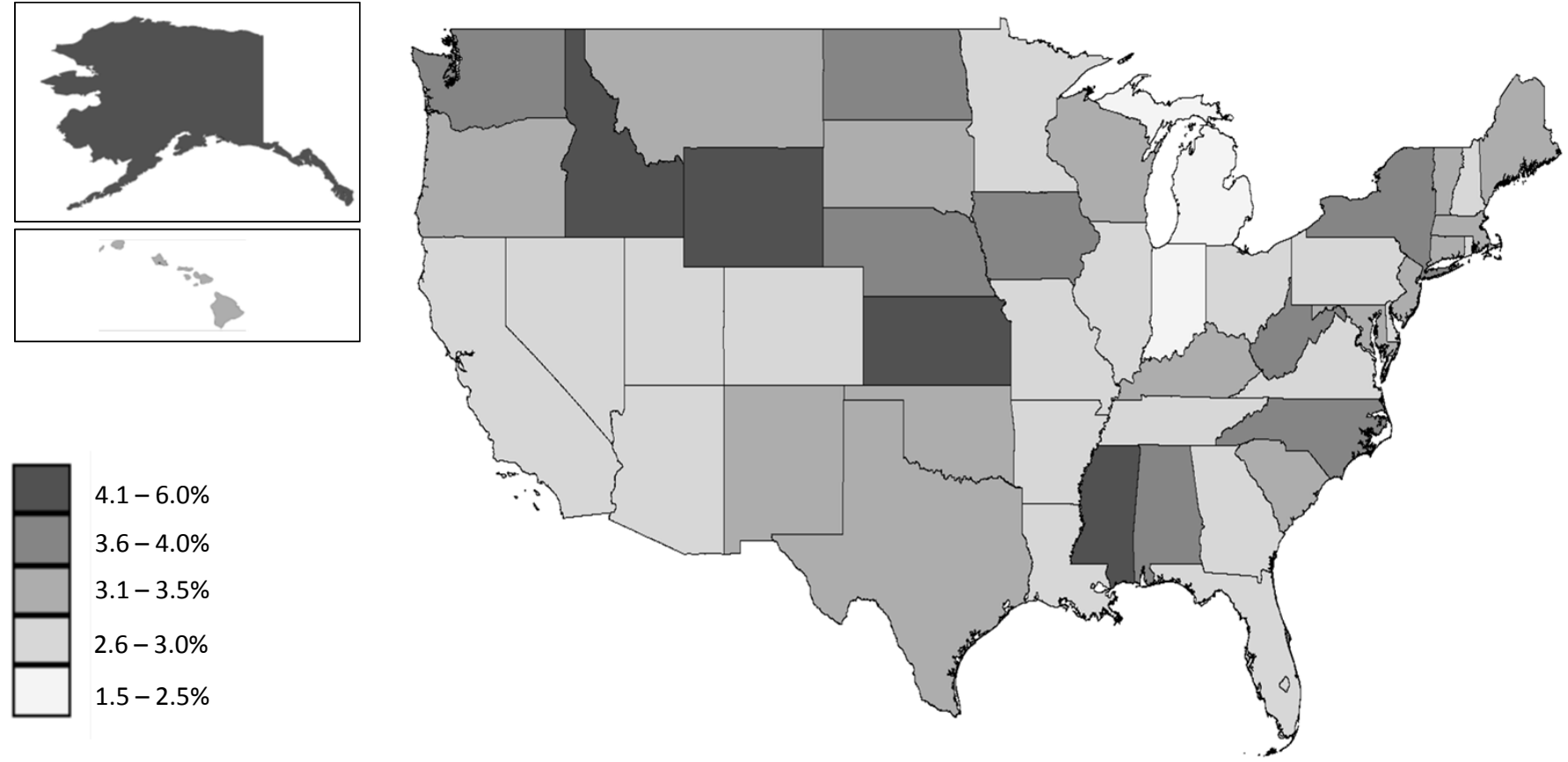

B) State and Local Government Retirees under Age 65 Years
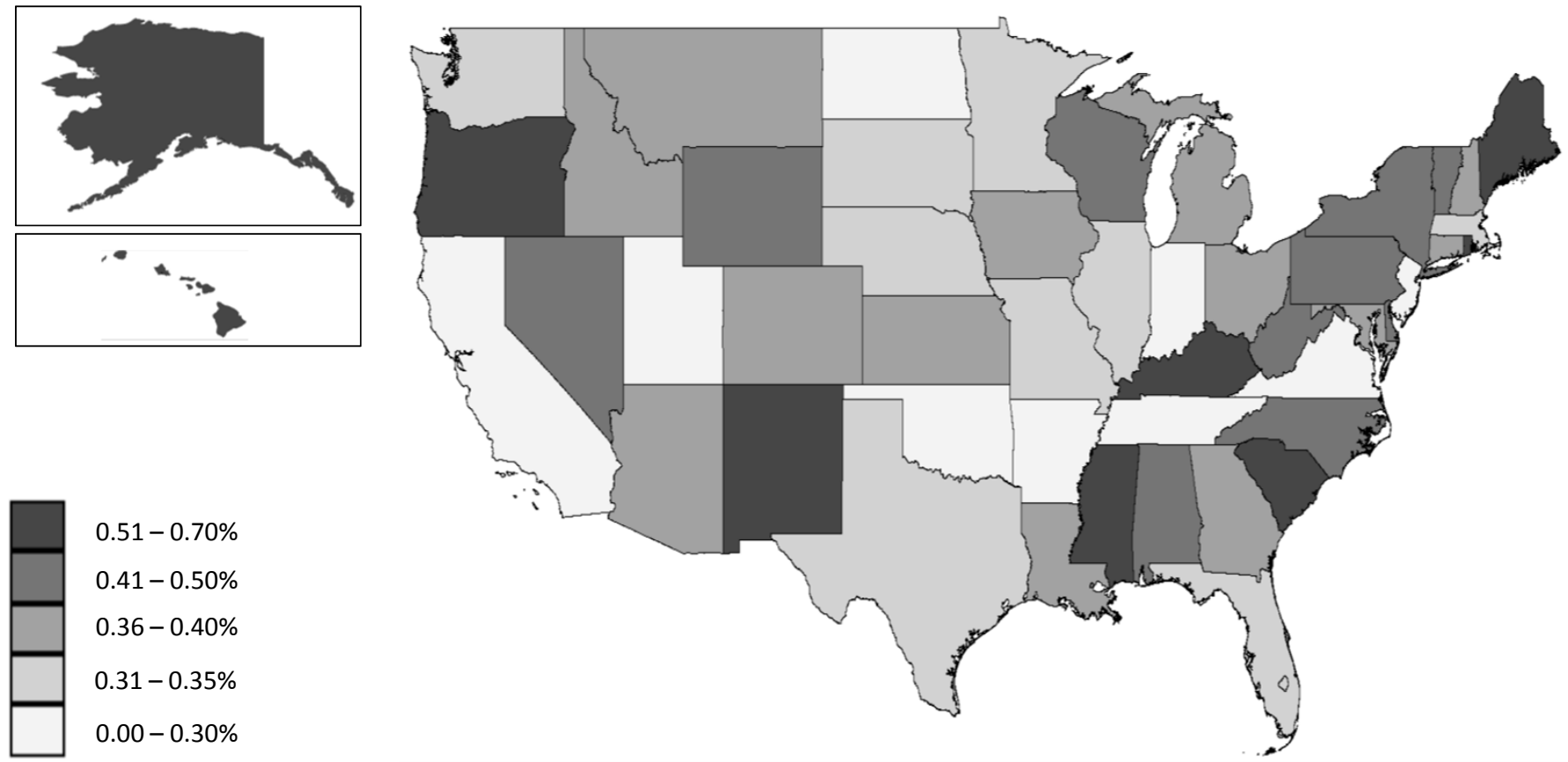

Note: This figures shows the proportions of each state's adult population that are state and local government workers or retirees below the age of 65 from such positions. Variation shown in the figures indicates substantial variation in the exposure states face to healthcare costs of their employees and retirees and consequently incentives from divestment. Source of data: Authors' calculations with U.S. Current Population Survey and Census Data on age-specific state populations 
Figure 2: Households of state and local governments workers and retirees below 65 years of age falling below $400 \%$ of the Federal Poverty Level

A) Employees and Retirees with Household Incomes between 138-400\% of the Federal Poverty Line
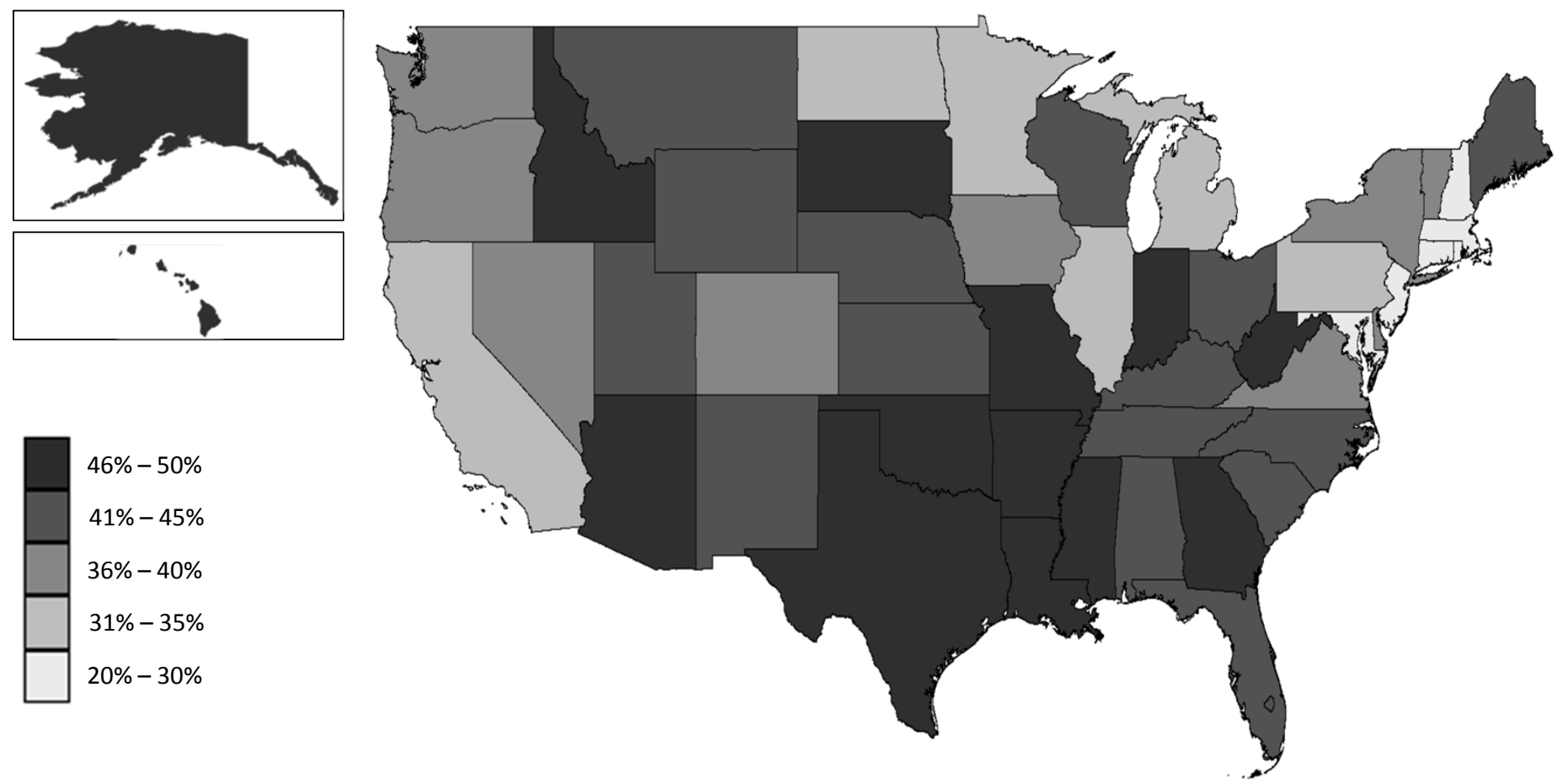

B) Employees and Retirees with Household Incomes below $138 \%$ of the Federal Poverty Line
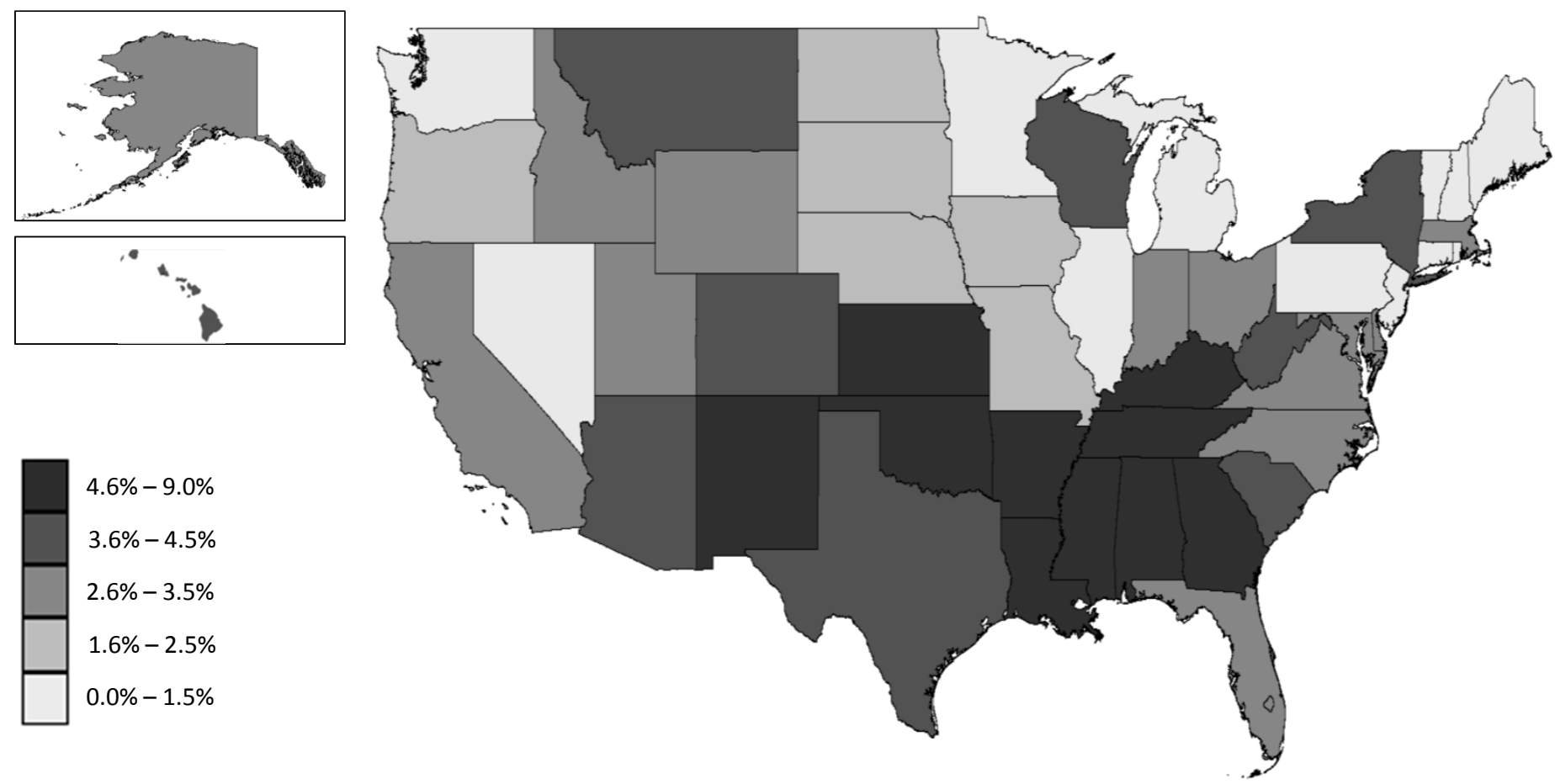

Note: This figures shows the proportions of state sand local government workers or retirees below the age of 65 from such positions whose households fall below $138 \%$ of the Federal Poverty Limit (FPL) - hence potentially eligible for federally subsidized Medicaid expansions - or within 138-400\% of the FPL - hence potentially eligible for federal subsidies and cost-sharing for insurance purchased on ACA exchanges. Variation shown in the figures indicates substantial variation in the potential for states to capture federal dollars through health insurance divestment. Source of data: Authors' calculations using U.S. Current Population Survey 
Appendix for "Will Divestment from Employment-Based Health Insurance Save Employers Money? The Case of State and Local Governments”

by

Jeremy D. Goldhaber-Fiebert, Monica Farid,

David Studdert, Jay Bhattacharya 
Appendix Sections:

1. Study Population

2. Average Annual Healthcare Expenditures

3. Workforces Sizes of State and Local Governments in Relationship to ACA Employer Penalties

4. Medicaid Expansions and Development of State Exchanges

5. Federal Subsidy and Cost-Sharing for ACA Exchange-Purchased Health Insurance Plans

6. Tax Effects of Income Supplements from State and Local Governments Whose Workers Move to Purchase Insurance on ACA Exchanges

7. State and Local Government Income Supplements, Federal Subsidies and CostSharing, and Tax Consequences: Two-Stage Fixed Point Method Technical Details

8. Additional Results and Supplemental Analyses

a. Status Quo Estimates

b. Full Divestment Strategy

c. Selective Divestment Strategy

d. Comparison of Healthcare Costs of Employee Households Shifting to Coverage under Exchange Plans and Those Continuing on State and Local Government-Provided Plans with the Selective Divestment Strategy 


\section{Study Population}

We consider two groups in our analysis, whose size we estimated using the CPS. The first group is current employees of State and Local Governments. The second group is made up of retirees from State and Local Governments. Additionally, we estimate the size of households of these individuals. The table below shows the estimated size of these groups.

Appendix Table 1. Estimates of the Number of Current Workers and Retirees from State and Local Governments under 65 Years of Age

\begin{tabular}{|c|c|c|c|c|}
\hline \multirow[b]{2}{*}{ State } & \multicolumn{2}{|c|}{ Current Workers } & \multicolumn{2}{|c|}{ Retirees below Age 65} \\
\hline & \# & $\begin{array}{c}\text { Average } \\
\text { Household } \\
\text { Size } \\
\end{array}$ & $\#$ & $\begin{array}{c}\text { Average } \\
\text { Household } \\
\text { Size }\end{array}$ \\
\hline Alabama & 217,000 & 3.4 & 30,000 & 3.0 \\
\hline Alaska & 53,000 & 3.6 & 6,000 & 2.9 \\
\hline Arizona & 222,000 & 3.8 & 31,000 & 2.4 \\
\hline Arkansas & 95,000 & 3.2 & 8,000 & 2.1 \\
\hline California & $1,397,000$ & 3.8 & 134,000 & 2.5 \\
\hline Colorado & 199,000 & 3.4 & 26,000 & 2.3 \\
\hline Connecticut & 148,000 & 3.6 & 17,000 & 2.7 \\
\hline Delaware & 30,000 & 3.3 & 5,000 & 2.1 \\
\hline District Of Columbia & 16,000 & 2.6 & 1,000 & 1.5 \\
\hline Florida & 636,000 & 3.2 & 74,000 & 2.6 \\
\hline Georgia & 375,000 & 3.5 & 49,000 & 2.4 \\
\hline Hawaii & 53,000 & 4.5 & 10,000 & 4.7 \\
\hline Idaho & 80,000 & 3.4 & 7,000 & 2.9 \\
\hline Illinois & 426,000 & 3.3 & 53,000 & 2.3 \\
\hline Indiana & 197,000 & 3.2 & 22,000 & 2.3 \\
\hline Iowa & 150,000 & 3.2 & 15,000 & 2.2 \\
\hline Kansas & 153,000 & 3.6 & 14,000 & 2.2 \\
\hline Kentucky & 172,000 & 3.1 & 34,000 & 2.4 \\
\hline Louisiana & 161,000 & 3.5 & 21,000 & 2.7 \\
\hline Maine & 53,000 & 3.2 & 9,000 & 2.6 \\
\hline Maryland & 236,000 & 3.6 & 29,000 & 3.1 \\
\hline Massachusetts & 266,000 & 3.4 & 30,000 & 2.2 \\
\hline Michigan & 299,000 & 3.6 & 48,000 & 2.6 \\
\hline Minnesota & 190,000 & 3.5 & 24,000 & 2.2 \\
\hline Mississippi & 157,000 & 3.4 & 23,000 & 2.2 \\
\hline Missouri & 213,000 & 3.6 & 24,000 & 2.5 \\
\hline Montana & 44,000 & 3.2 & 5,000 & 2.0 \\
\hline Nebraska & 86,000 & 3.4 & 7,000 & 3.0 \\
\hline Nevada & 95,000 & 3.8 & 15,000 & 2.5 \\
\hline New Hampshire & 48,000 & 3.3 & 7,000 & 2.6 \\
\hline New Jersey & 341,000 & 3.6 & 30,000 & 3.0 \\
\hline New Mexico & 90,000 & 3.5 & 15,000 & 2.5 \\
\hline New York & 921,000 & 3.6 & 108,000 & 2.7 \\
\hline North Carolina & 474,000 & 3.3 & 54,000 & 2.3 \\
\hline North Dakota & 34,000 & 3.3 & 3,000 & 2.2 \\
\hline Ohio & 397,000 & 3.5 & 56,000 & 2.6 \\
\hline Oklahoma & 161,000 & 3.5 & 10,000 & 2.8 \\
\hline
\end{tabular}




\begin{tabular}{|l|r|r|r|r|}
\hline Oregon & 173,000 & 3.3 & 32,000 & 2.2 \\
\hline Pennsylvania & 418,000 & 3.4 & 77,000 & 2.8 \\
\hline Rhode Island & 37,000 & 3.5 & 8,000 & 2.5 \\
\hline South Carolina & 195,000 & 3.3 & 41,000 & 2.4 \\
\hline South Dakota & 33,000 & 3.5 & 3,000 & 2.2 \\
\hline Tennessee & 209,000 & 3.2 & 15,000 & 2.2 \\
\hline Texas & 999,000 & 3.6 & 108,000 & 2.6 \\
\hline Utah & 91,000 & 4.1 & 9,000 & 2.6 \\
\hline Vermont & 27,000 & 3.3 & 3,000 & 2.7 \\
\hline Virginia & 266,000 & 3.3 & 28,000 & 2.2 \\
\hline Washington & 316,000 & 3.4 & 29,000 & 2.5 \\
\hline West Virginia & 93,000 & 3.1 & 10,000 & 1.9 \\
\hline Wisconsin & 228,000 & 3.6 & 31,000 & 2.2 \\
\hline Wyoming & 40,000 & 3.3 & 3,000 & 2.8 \\
\hline NATIONAL & $\mathbf{1 2 , 0 0 8 , 0 0 0}$ & $\mathbf{3 . 5}$ & $\mathbf{1 , 4 5 5 , 0 0 0}$ & $\mathbf{2 . 5}$ \\
\hline
\end{tabular}




\section{Average Annual Healthcare Expenditures}

An individual's healthcare expenditures and those of his or her household act as reasonably close proxy for total health insurance premium payments. We used data from MEPS to estimate average annual medical expenditures for individuals conditional on their age, sex, and region of the country in which they reside (see description further below). With these estimates we predicted the average annual total healthcare costs of current State and Local Government Employees, Retirees from these jobs under age 65 years, and the households of these individuals. As a face validity check, we compared these predictions to the price of Silver Plans on ACA Exchanges with the knowledge that State and Local Government benefits and insurance are typically more generous than for comparable jobs in the private sector and hence expenditures in these households may be higher than average. Appendix Table 2 shows a comparison of our predictions to the premiums for a Silver Plan confirming that predicted average healthcare spending (our proxy for premiums) in our group was higher than the Silver Plan premium amounts, often closer to the Gold or Platinum Plans. Of note, these comparisons are made with the total healthcare expenditures and not only the percentage of insurance premiums typically covered by the State and Local Government employer.

Appendix Table 2. How Much Do Estimated Average Annual Healthcare Expenditures Exceed Silver Plans on ACA Exchanges for Comparable Household Sizes

\begin{tabular}{|l|r|r|}
\hline & \multicolumn{2}{|c|}{ Household Size } \\
\hline Alabama & 1 person & 4 people \\
\hline Alaska & $\$ 1,453$ & $\$ 787$ \\
\hline Arizona & $\$ 1,778$ & $\$ 1,649$ \\
\hline Arkansas & $\$ 936$ & $\$ 546$ \\
\hline California & $\$ 1,000$ & $\$ 2,529$ \\
\hline Colorado & $\$ 1,431$ & $\$ 1,533$ \\
\hline Connecticut & $\$ 1,099$ & $\$ 540$ \\
\hline Delaware & $\$ 1,224$ & $\$ 4,285$ \\
\hline District Of Columbia & $\$ 2,342$ & $\$ 1,501$ \\
\hline Florida & $\$ 811$ & $\$ 1,427$ \\
\hline Georgia & $\$ 1,534$ & $\$ 1,180$ \\
\hline Hawaii & $\$ 1,631$ & $\$ 1,183$ \\
\hline Idaho & $\$ 1,683$ & $\$ 2,875$ \\
\hline Illinois & $\$ 2,756$ & $\$ 3,930$ \\
\hline Indiana & $\$ 2,547$ & $\$ 3,612$ \\
\hline Iowa & $\$ 2,431$ & $\$ 2,990$ \\
\hline Kansas & $\$ 2,423$ & $\$ 3,129$ \\
\hline Kentucky & $\$ 280$ & $\$ 780$ \\
\hline Louisiana & $\$ 786$ & $\$ 886$ \\
\hline Maine & $\$ 2,863$ & $\$ 3,524$ \\
\hline Maryland & $\$ 1,547$ & $\$ 1,643$ \\
\hline Massachusetts & $\$ 1,492$ & $\$ 3,322$ \\
\hline Michigan & $\$ 2,179$ & $\$ 3,748$ \\
\hline Minnesota & $\$ 2,681$ & $\$ 4,181$ \\
\hline Mississippi & $\$ 1,319$ & $\$ 1,321$ \\
\hline Missouri & $\$ 1,980$ & $\$ 3,082$ \\
\hline Montana & $\$ 1,373$ & $\$ 775$ \\
\hline Nebraska & $\$ 2,357$ & $\$ 2,915$ \\
\hline Nevada & $\$ 1,756$ & $\$ 973$ \\
\hline
\end{tabular}




\begin{tabular}{|l|r|r|}
\hline New Hampshire & $\$ 2,246$ & $\$ 3,210$ \\
\hline New Jersey & $\$ 1,536$ & $\$ 4,209$ \\
\hline New Mexico & $\$ 1,581$ & $\$ 202$ \\
\hline New York & $\$ 1,810$ & $\$ 3,671$ \\
\hline North Carolina & $\$ 1,509$ & $\$ 597$ \\
\hline North Dakota & $\$ 1,964$ & $\$ 2,936$ \\
\hline Ohio & $\$ 1,610$ & $\$ 3,275$ \\
\hline Oklahoma & $\$ 2,017$ & $(\$ 120)$ \\
\hline Oregon & $\$ 1,110$ & $\$ 232$ \\
\hline Pennsylvania & $\$ 1,607$ & $\$ 3,255$ \\
\hline Rhode Island & $\$ 2,129$ & $\$ 4,113$ \\
\hline South Carolina & $\$ 2,198$ & $\$ 1,667$ \\
\hline South Dakota & $\$ 2,562$ & $\$ 2,364$ \\
\hline Tennessee & $\$ 1,542$ & $\$ 1,554$ \\
\hline Texas & $\$ 1,421$ & $\$ 1,186$ \\
\hline Utah & $\$ 947$ & $\$ 459$ \\
\hline Vermont & $\$ 2,105$ & $\$ 3,175$ \\
\hline Virginia & $\$ 1,861$ & $\$ 1,592$ \\
\hline Washington & $\$ 1,457$ & $\$ 700$ \\
\hline West Virginia & $\$ 1,624$ & $\$ 990$ \\
\hline Wisconsin & $\$ 2,786$ & $\$ 2,794$ \\
\hline Wyoming & $\$ 1,558$ & $\$ 604$ \\
\hline
\end{tabular}

We used the MEPS annual individual total healthcare expenditure inflated to 2013 US dollars using the medical component of the Consumer Price Index and adjusted, as described in the manuscript, to account for loading fees and undercounts of pharmaceutical costs along with data on the age, sex, and region (Northeast, South, Midwest, or West) to form our predictions of annual individual expenditure for our two study populations. To allow for a flexible non-linear relationship between age and medical expenditures, the regression used restricted cubic splines for age in years with knots placed at 15 year intervals from age 0 through age 75 and an additional knot at age 85, though notably since the analysis focused on individuals below retirement age, predictions on the under-65 populations were all that was used. Region entered the regression as a set of dummy variables (reference category is Northeast) as did sex (reference category is Female). The dummy variables were interacted with each other, age splines, and the combination of the three. The regression model results are shown below and for greater clarity and ease of interpretation, the predicted expenditure patterns by age, sex, and region are shown in Appendix Figure 1 below.

\begin{tabular}{|c|c|c|c|c|c|}
\hline Coefficient & Beta & $\begin{array}{c}\text { Robust } \\
\text { Standard } \\
\text { Error }\end{array}$ & p-value & $95 \% \mathrm{CI}$ & \\
\hline Age Spline 0-15 & 113.6236 & 54.98912 & 2.07 & 0.039 & 5.8461 \\
\hline Age Spline 15-30 & -221.6278 & 668.247 & -0.33 & 0.74 & -1531.377 \\
\hline Age Spline 30-45 & 681.3117 & 2095.15 & 0.33 & 0.745 & -3425.136 \\
\hline Age Spline 45-60 & -424.8395 & 3128.349 & -0.14 & 0.892 & -6556.335 \\
\hline Age Spline 60-75 & 1562.184 & 4151.349 & 0.38 & 0.707 & -6574.369 \\
\hline Age Spline 75-85 & -5999.623 & 6148.192 & -0.98 & 0.329 & -18049.94 \\
\hline \multicolumn{6}{|l|}{ Region } \\
\hline Midwest & 769.0377 & 717.037 & 1.07 & 0.283 & -636.3392 \\
\hline South & 727.1344 & 731.9545 & 0.99 & 0.321 & -707.4804 \\
\hline West & -87.49932 & 480.9301 & -0.18 & 0.856 & -1030.112 \\
\hline
\end{tabular}




\begin{tabular}{|c|c|c|c|c|c|}
\hline \multicolumn{6}{|c|}{ Region * Age Spline (0-15) } \\
\hline Midwest & -159.6188 & 87.44735 & -1.83 & 0.068 & -331.0137 \\
\hline South & -183.982 & 82.7739 & -2.22 & 0.026 & -346.217 \\
\hline West & -113.6085 & 64.16526 & -1.77 & 0.077 & -239.371 \\
\hline \multicolumn{6}{|c|}{ Region* Age Spline (15-30) } \\
\hline Midwest & 2327.005 & 955.3503 & 2.44 & 0.015 & 454.5391 \\
\hline South & 2149.976 & 872.9558 & 2.46 & 0.014 & 439.0022 \\
\hline West & 1459.76 & 809.3271 & 1.8 & 0.071 & -126.503 \\
\hline \multicolumn{6}{|c|}{ Region * Age Spline (30-45) } \\
\hline Midwest & -7397.975 & 2937.612 & -2.52 & 0.012 & -13155.63 \\
\hline South & -6506.44 & 2646.13 & -2.46 & 0.014 & -11692.8 \\
\hline West & -3825.126 & 2790.103 & -1.37 & 0.17 & -9293.667 \\
\hline \multicolumn{6}{|c|}{ Region * Age Spline (45-60) } \\
\hline Midwest & 11057.04 & 4402.151 & 2.51 & 0.012 & 2428.917 \\
\hline South & 8843.475 & 3834.575 & 2.31 & 0.021 & 1327.792 \\
\hline West & 3251.278 & 5161.049 & 0.63 & 0.529 & -6864.266 \\
\hline \multicolumn{6}{|c|}{ Region* Age Spline (60-75) } \\
\hline Midwest & -13346.48 & 5883.159 & -2.27 & 0.023 & -24877.35 \\
\hline South & -9512.011 & 4967.089 & -1.92 & 0.055 & -19247.4 \\
\hline West & -1571.384 & 7656.267 & -0.21 & 0.837 & -16577.5 \\
\hline \multicolumn{6}{|c|}{ Region * Age Spline (75-85) } \\
\hline Midwest & 13649.34 & 8240.647 & 1.66 & 0.098 & -2502.15 \\
\hline South & 9871.189 & 7235.822 & 1.36 & 0.173 & -4310.865 \\
\hline West & 2217.815 & 10188.96 & 0.22 & 0.828 & -17752.32 \\
\hline Male & 529.6052 & 551.7665 & 0.96 & 0.337 & -551.845 \\
\hline \multicolumn{6}{|c|}{ Male * Age Spline (0-15) } \\
\hline Male & -56.0196 & 76.7225 & -0.73 & 0.465 & -206.394 \\
\hline \multicolumn{6}{|c|}{ Male * Age Spline (15-30) } \\
\hline Male & -960.8822 & 974.2302 & -0.99 & 0.324 & -2870.352 \\
\hline \multicolumn{6}{|c|}{ Male * Age Spline (30-45) } \\
\hline Male & 4688.839 & 3349.559 & 1.4 & 0.162 & -1876.224 \\
\hline \multicolumn{6}{|c|}{ Male * Age Spline (45-60) } \\
\hline Male & -8097.658 & 6199.041 & -1.31 & 0.191 & -20247.64 \\
\hline \multicolumn{6}{|c|}{ Male * Age Spline (60-75) } \\
\hline Male & 5973.889 & 9816.104 & 0.61 & 0.543 & -13265.46 \\
\hline \multicolumn{6}{|c|}{ Male * Age Spline (75-85) } \\
\hline Male & -2442.451 & 13689.86 & -0.18 & 0.858 & -29274.28 \\
\hline \multicolumn{6}{|l|}{ Region * Male } \\
\hline Midwest, Male & -310.9885 & 929.8945 & -0.33 & 0.738 & -2133.561 \\
\hline South, Male & -858.9727 & 846.022 & -1.02 & 0.31 & -2517.157 \\
\hline West, Male & -485.8696 & 664.8764 & -0.73 & 0.465 & -1789.013 \\
\hline \multicolumn{6}{|c|}{ Region * Male * Age Spline (0-15) } \\
\hline Midwest, Male & 81.54219 & 117.1654 & 0.7 & 0.486 & -148.0994 \\
\hline South, Male & 124.5319 & 103.5665 & 1.2 & 0.229 & -78.45623 \\
\hline
\end{tabular}




\begin{tabular}{|c|c|c|c|c|c|}
\hline West, Male & 96.6155 & 95.29748 & 1.01 & 0.311 & -90.16548 \\
\hline \multicolumn{6}{|c|}{ Region * Male * Age Spline (15-30) } \\
\hline Midwest, Male & -1172.715 & 1338.257 & -0.88 & 0.381 & -3795.669 \\
\hline South, Male & -1319.967 & 1190.05 & -1.11 & 0.267 & -3652.439 \\
\hline West, Male & -683.0241 & 1194.532 & -0.57 & 0.567 & -3024.281 \\
\hline \multicolumn{6}{|c|}{ Region * Male * Age Spline (30-45) } \\
\hline Midwest, Male & 2882.241 & 4371.593 & 0.66 & 0.51 & -5685.986 \\
\hline South, Male & 3532.036 & 3932.19 & 0.9 & 0.369 & -4174.97 \\
\hline West, Male & -133.6795 & 4154.981 & -0.03 & 0.974 & -8277.352 \\
\hline \multicolumn{6}{|c|}{ Region * Male * Age Spline (45-60) } \\
\hline Midwest, Male & -2012.342 & 7531.788 & -0.27 & 0.789 & -16774.48 \\
\hline South, Male & -3853.203 & 6903.38 & -0.56 & 0.577 & -17383.68 \\
\hline West, Male & 5739.409 & 7886.26 & 0.73 & 0.467 & -9717.488 \\
\hline \multicolumn{6}{|c|}{ Region * Male * Age Spline (60-75) } \\
\hline Midwest, Male & 686.8747 & 11417.13 & 0.06 & 0.952 & -21690.45 \\
\hline South, Male & 4239.114 & 10635.73 & 0.4 & 0.69 & -16606.69 \\
\hline West, Male & -10748.51 & 12392.24 & -0.87 & 0.386 & -35037.02 \\
\hline \multicolumn{6}{|c|}{ Region * Male * Age Spline (75-85) } \\
\hline Midwest, Male & 1135.603 & 16118.24 & 0.07 & 0.944 & -30455.8 \\
\hline South, Male & -4350.547 & 15120 & -0.29 & 0.774 & -33985.41 \\
\hline West, Male & 11140.72 & 17229.77 & 0.65 & 0.518 & -22629.26 \\
\hline Constant & 1697.256 & 413.875 & 4.1 & 0 & 886.0698 \\
\hline
\end{tabular}

$\mathrm{N}=167,279 ; \mathrm{F}(55,167223)=113.38 ;$ Prob $>$ F $<$ 0.0001; R-squared = 0.0624; Root MSE = 16,105 
Appendix Figure 1. Average Annual Medical Expenditures Including Pharmaceuticals (USD 2013) By Age, Sex, and US Geographic Region
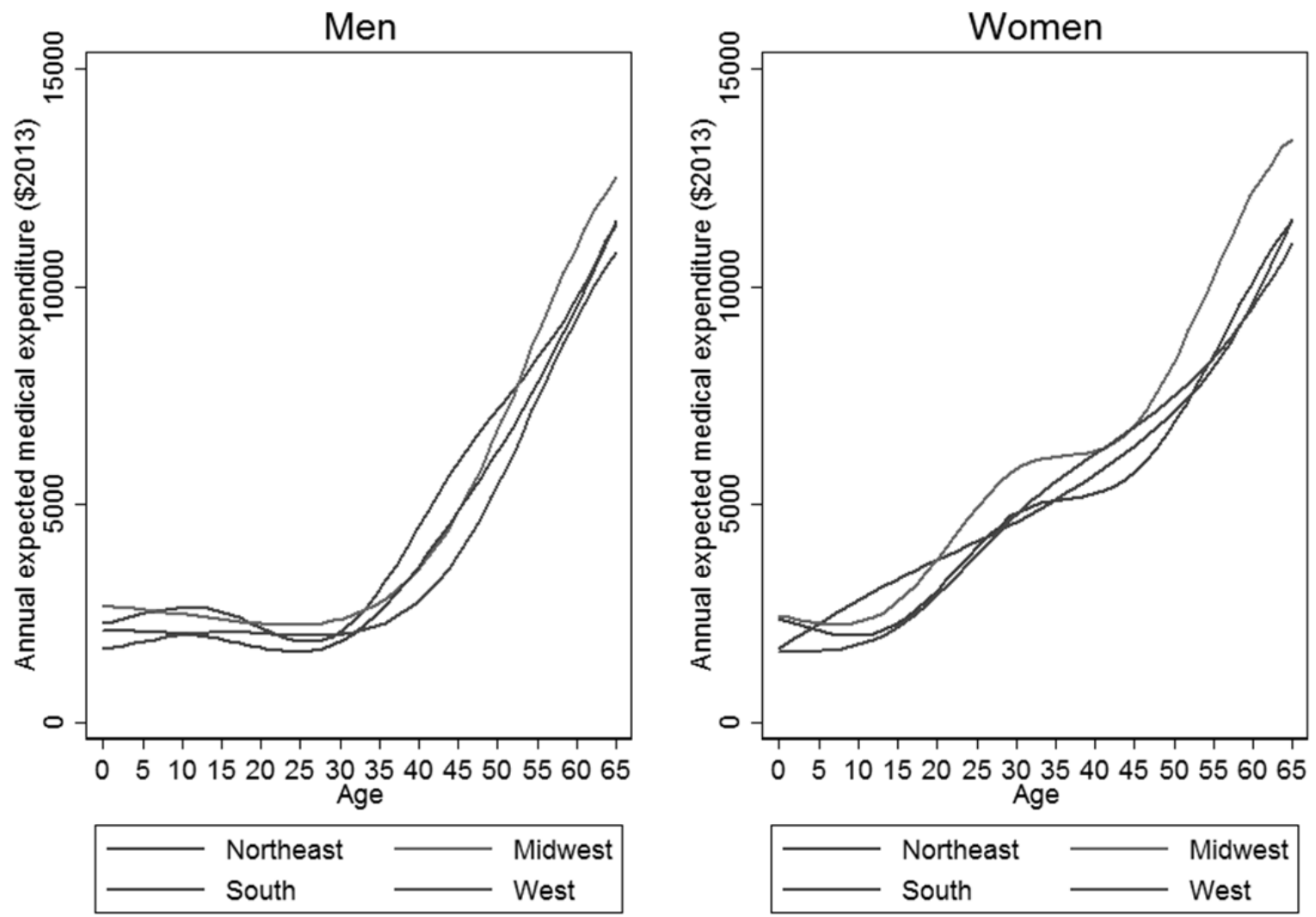


\section{Workforces Sizes of State and Local Governments in Relationship to ACA Employer Penalties}

We used 2011 APES data to provide an independent estimate of the size of our study population as a face validation check and more importantly to characterize the percentage of state and local government workers working for governments of different sizes. The latter was particularly relevant because employer penalties are determined by the number of full-time workers above 30. Since the CPS does not allow linking individual workers to specific State or Local Government entities, it was important to establish that the overwhelming majority of workers work for governments whose total number of employees exceeds several hundred. This would mean that the likelihood of at least one employee receiving subsidies or cost-sharing for purchasing insurance on ACA exchanges is high and that the average per-capita penalty for that government entity would be very close to $\$ 2,000$ should it choose to cancel its provision of insurance entirely. Appendix Table 3 shows both of these assumptions to be highly credible.

Appendix Table 3. Distribution of Sizes of State and Local Government Workforces According to the 2011 APES and the Implied size of the Employer Penalty for Firms of Corresponding Sizes

\begin{tabular}{|c|r|r|r|}
\hline $\begin{array}{c}\text { Size of Government Workforce } \\
\text { (Number of Full-time Employees) }\end{array}$ & $\begin{array}{c}\text { Average Per- } \\
\text { Capita Penalty } \\
\mathbf{( \$ )}\end{array}$ & $\begin{array}{c}\text { Total Number of State and } \\
\text { Local Governments }\end{array}$ & $\begin{array}{c}\text { Total Number of Full- } \\
\text { Time Employees }\end{array}$ \\
\hline $\mathbf{3 0}$ and below & 0 & 3,290 & 41,914 \\
\hline $\mathbf{3 1}$ & 65 & 1 & 31 \\
\hline $\mathbf{3 2 - 3 3}$ & 163 & 6 & 196 \\
\hline $\mathbf{3 4 - 3 5}$ & 264 & 7 & 242 \\
\hline $\mathbf{3 6 - 3 7}$ & 356 & 6 & 219 \\
\hline $\mathbf{3 8 - 3 9}$ & 451 & 11 & 426 \\
\hline $\mathbf{4 0 - 4 2}$ & 533 & 23 & 941 \\
\hline $\mathbf{4 3 - 4 6}$ & 658 & 47 & 2,102 \\
\hline $\mathbf{4 7 - 4 9}$ & 749 & 40 & 1,919 \\
\hline $\mathbf{5 0 - 5 4}$ & 846 & 122 & 6,344 \\
\hline $\mathbf{5 5}-59$ & 944 & 125 & 7,103 \\
\hline $\mathbf{6 0 - 6 6}$ & 1,050 & 162 & 10,229 \\
\hline $\mathbf{6 7 - 7 4}$ & 1,148 & 156 & 10,989 \\
\hline $\mathbf{7 5 - 8 5}$ & 1,252 & 243 & 19,489 \\
\hline $\mathbf{8 6 - 9 9}$ & 1,352 & 281 & 26,034 \\
\hline $\mathbf{1 0 0 - 1 1 9}$ & 1,452 & 315 & 34,508 \\
\hline $\mathbf{1 2 0}-149$ & 1,552 & 450 & 60,252 \\
\hline $\mathbf{1 5 0 - 1 9 9}$ & 1,654 & 642 & 111,263 \\
\hline $\mathbf{2 0 0}-299$ & 1,757 & 834 & 206,306 \\
\hline $\mathbf{3 0 0 - 5 9 9}$ & 1,861 & 1,229 & 532,079 \\
\hline $\mathbf{6 0 0}+$ & 1,985 & 2,522 & $10,400,000$ \\
\hline $\mathbf{T O T A L}$ & & $\mathbf{1 0 , 5 1 2}$ & $\mathbf{1 1 , 4 7 2 , 5 6 8}$ \\
\hline
\end{tabular}




\section{Medicaid Expansions and Development of State Exchanges}

State Medicaid expansions are important given that under the ACA the federal government supports these expansions. However, such expansions are a moving target - as some states have not implemented them without any current intention of doing so and others have not implemented but are contemplating expansions more actively. We used data reported by the Kaiser Family Foundation monitoring current implementations of Medicaid expansions as of January 28, 2014 as shown in the table below.

Appendix Table 4. Medicaid Expansions for Implementation in 2014 According to the Kaiser Family Foundation

\begin{tabular}{|c|c|}
\hline State & $\begin{array}{c}\text { Implementing Expansion } \\
\text { in } 2014\end{array}$ \\
\hline Alabama & No \\
\hline Alaska & No \\
\hline Arizona & Yes \\
\hline Arkansas & Yes \\
\hline California & Yes \\
\hline Colorado & Yes \\
\hline Connecticut & Yes \\
\hline Delaware & Yes \\
\hline District of Columbia & Yes \\
\hline Florida & No \\
\hline Georgia & No \\
\hline Hawaii & Yes \\
\hline Idaho & No \\
\hline Illinois & Yes \\
\hline Indiana & No \\
\hline Iowa & Yes \\
\hline Kansas & No \\
\hline Kentucky & Yes \\
\hline Louisiana & No \\
\hline Maine & No \\
\hline Maryland & Yes \\
\hline Massachusetts & Yes \\
\hline Michigan & Yes \\
\hline Minnesota & Yes \\
\hline Mississippi & No \\
\hline Missouri & No \\
\hline Montana & No \\
\hline Nebraska & No \\
\hline Nevada & Yes \\
\hline New Hampshire & No \\
\hline New Jersey & Yes \\
\hline New Mexico & Yes \\
\hline New York & Yes \\
\hline North Carolina & No \\
\hline North Dakota & Yes \\
\hline Ohio & Yes \\
\hline Oklahoma & No \\
\hline Oregon & Yes \\
\hline Pennsylvania & No \\
\hline
\end{tabular}




\begin{tabular}{|l|l|}
\hline Rhode Island & Yes \\
\hline South Carolina & No \\
\hline South Dakota & No \\
\hline Tennessee & No \\
\hline Texas & No \\
\hline Utah & No \\
\hline Vermont & Yes \\
\hline Virginia & No \\
\hline Washington & Yes \\
\hline West Virginia & Yes \\
\hline Wisconsin & No \\
\hline Wyoming & No \\
\hline
\end{tabular}

Likewise, given Supreme Court considerations in cases like King v Burwell, the type of ACA exchange in a state may determine whether subsidies and cost-sharing are available to otherwise qualifying individuals purchasing insurance via the exchange. Given uncertainty in the availability of subsidies and cost-sharing should the case be decided that federal exchanges do not qualify, we performed a sensitivity analysis only estimating savings in states that had such exchanges. For this sensitivity analysis, we use data from a Kaiser Family Foundation report characterizing state exchange types.

\begin{tabular}{|c|c|c|}
\hline State & Exchange Type & $\begin{array}{c}\text { Subsidy Eligible } \\
\text { Regardless of } \\
\text { Supreme Court } \\
\text { Ruling }\end{array}$ \\
\hline Alabama & Federally-facilitated Marketplace & No \\
\hline Alaska & Federally-facilitated Marketplace & No \\
\hline Arizona & Federally-facilitated Marketplace & No \\
\hline Arkansas & State-Partnership Marketplace & No \\
\hline California & State-based Marketplace & Yes \\
\hline Colorado & State-based Marketplace & Yes \\
\hline Connecticut & State-based Marketplace & Yes \\
\hline Delaware & State-Partnership Marketplace & No \\
\hline District of Columbia & State-based Marketplace & Yes \\
\hline Florida & Federally-facilitated Marketplace & No \\
\hline Georgia & Federally-facilitated Marketplace & No \\
\hline Hawaii & State-based Marketplace & Yes \\
\hline Idaho & State-based Marketplace & Yes \\
\hline Illinois & State-Partnership Marketplace & No \\
\hline Indiana & Federally-facilitated Marketplace & No \\
\hline Iowa & State-Partnership Marketplace & No \\
\hline Kansas & Federally-facilitated Marketplace & No \\
\hline Kentucky & State-based Marketplace & Yes \\
\hline Louisiana & Federally-facilitated Marketplace & No \\
\hline Maine & Federally-facilitated Marketplace & No \\
\hline Maryland & State-based Marketplace & Yes \\
\hline Massachusetts & State-based Marketplace & Yes \\
\hline Michigan & State-Partnership Marketplace & No \\
\hline Minnesota & State-based Marketplace & Yes \\
\hline Mississippi & Federally-facilitated Marketplace & No \\
\hline Missouri & Federally-facilitated Marketplace & No \\
\hline Montana & Federally-facilitated Marketplace & No \\
\hline
\end{tabular}




\begin{tabular}{|l|l|c|}
\hline Nebraska & Federally-facilitated Marketplace & No \\
\hline Nevada & Federally-supported State-based Marketplace & Yes \\
\hline New Hampshire & State-Partnership Marketplace & No \\
\hline New Jersey & Federally-facilitated Marketplace & No \\
\hline New Mexico & Federally-supported State-based Marketplace & Yes \\
\hline New York & State-based Marketplace & Yes \\
\hline North Carolina & Federally-facilitated Marketplace & No \\
\hline North Dakota & Federally-facilitated Marketplace & No \\
\hline Ohio & Federally-facilitated Marketplace & No \\
\hline Oklahoma & Federally-facilitated Marketplace & No \\
\hline Oregon & Federally-supported State-based Marketplace & Yes \\
\hline Pennsylvania & Federally-facilitated Marketplace & No \\
\hline Rhode Island & State-based Marketplace & Yes \\
\hline South Carolina & Federally-facilitated Marketplace & No \\
\hline South Dakota & Federally-facilitated Marketplace & No \\
\hline Tennessee & Federally-facilitated Marketplace & No \\
\hline Texas & Federally-facilitated Marketplace & No \\
\hline Utah & Federally-facilitated Marketplace & No \\
\hline Vermont & State-based Marketplace & Yes \\
\hline Virginia & Federally-facilitated Marketplace & No \\
\hline Washington & State-based Marketplace & Yes \\
\hline West Virginia & State-Partnership Marketplace & No \\
\hline Wisconsin & Federally-facilitated Marketplace & No \\
\hline Wyoming & Federally-facilitated Marketplace & No \\
\hline
\end{tabular}




\section{Federal Subsidy and Cost-Sharing for ACA Exchange-Purchased Health Insurance Plans}

For individuals purchasing health insurance on the ACA exchanges, federal subsidies and cost sharing may be available depending on their household income and their expected medical expenditures relative to the Silver Plan premium payments for households of equivalent size. Subsidies are computed based on tiers of household income as a percentage of the Federal Poverty Level: 138-149, 150-199, 200-249, 250-299, and 300-400 percent of the Federal Poverty Level respectively. To determine the subsidy amount, the subsidy percentage is multiplied by the total household income, and this amount is then subtracted from the price of a Silver Plan for a household of size 1, 2, or 3+ individuals according to the size of each household in the affected population. The price of the Silver Plan for a household of one individual is \$4,914 and \$13,591 for a household of 4 in in 2013 dollars. Likewise, cost-sharing percentages are based on tiers from 138-149, 150-199, 200-249, and 250-400 percent of the Federal Poverty Level. To determine the cost-sharing amount, the cost-sharing percentage is multiplied by the total expected annual household medical expenditure. 


\section{Tax Effects of Income Supplements from State and Local Governments Whose Workers Move to Purchase Insurance on ACA Exchanges}

For federal income taxes, we classified each CPS household as being a single filer, married joint filer, or head of household filer. Then, based on their Adjusted Gross Income (AGI), we

computed their total tax burden based on 2013 AGI cutoffs for marginal tax rates of 10\%, 15\%, 25\%, 28\%, 33\%, 35\%, and 39.6\%. Assuming State and Local Governments wanted to make their current workers as well off as they currently are after divesting from health care coverage, we computed the amount of additional compensation that would need to be paid by SLGs to their employees to offset both the cost of health insurance premium payments (net federal subsidies and cost-sharing which also depend on the amount of the additional compensation) as well as to cover increases in tax liabilities, using a two-step fixed point method (detailed below). 


\section{State and Local Government Income Supplements, Federal Subsidies and Cost-Sharing, and Tax Consequences: Two-Stage Fixed Point Method Technical Details}

To make our estimates of State and Local Government savings by divesting from the provision of health insurance, we needed to compute the amount State and Local Government income supplements net of federal subsidies and cost-sharing and compensating for their impact on an individual's federal tax bill. As federal subsidies and cost-sharing depended on total household income relative to the Federal Poverty Level and the tax bill depended on Adjusted Gross Income, simultaneously computing these quantities implied dealing with their interdependency. To do so, we used an iterative, two-step, fixed point method.

First, we define three functions of Household Income $(I)$ and Household Size and Demographic Structure $(F)$.

1) Subsidies (Federal Subsidy and Cost-Sharing) Function: $\theta_{S}:(I, F) \rightarrow S$

2) Health Insurance Premium Payment Function: $\theta_{P}:(I, F) \rightarrow P$

3) Federal Tax Bill Function: $\theta_{\tau}:(I, F) \rightarrow \tau$

We compute initial values for Premium Payments $\left(P_{0}\right)$, Subsidies $\left(S_{0}\right)$ and Taxes $\left(T_{0}\right)$ independent of one another:

$$
\begin{aligned}
& P_{0}=\theta_{P}(I, F) \\
& S_{0}=\theta_{S}(I, F) \\
& \tau_{0}=\theta_{\tau}(I, F)
\end{aligned}
$$

We notice that Premium Payments are determined entirely by the Household Size and Demographic Structure so $P_{0}$ will remain fixed at $P$ which we use unsubscripted for the subsequent description below.

In our first step of our two-step approach, we update the Subsidies to account for premium support that increases income provided by the State and Local government and likewise recomputed Taxes based on this increase to income:

$$
\begin{aligned}
& S_{1}=\theta_{S}\left(I+P-S_{0}, F\right) \\
& \tau_{1}=\theta_{\tau}\left(I+P-S_{0}, F\right)
\end{aligned}
$$

In our second step of our two-step approach, to ensure that the individual receives enough additional income so that increases to the tax bill are compensated for, we update the Taxes based on the following:

$$
\begin{gathered}
\Delta \tau=\tau_{1}-\tau_{0} \\
S_{2}=\theta_{S}\left(I+P-S_{2}+\Delta \tau, F\right) \\
\tau_{2}=\theta_{\tau}\left(I+P-S_{2}+\Delta \tau, F\right)
\end{gathered}
$$


The system of equations has a fixed point. First, the Health Insurance Premium Payments (P) for a fixed value of $\mathrm{F}$ and do not depend on income. Second, the Subsidies $(S)$ are a declining function of income for a fixed value of $F$. Third, Taxes is an increasing function of income for a fixed value of $F$, but stabilizes to a function of elements that do not depend on subsidies once income exceeds $400 \%$ of the Federal Poverty Level and hence subsidies are 0 .

We rely on a numerical approximation of this fixed point by iteratively repeating this two-step computation 50 times $S_{2}$ in a given iteration replaces $S_{0}$ for the start of the next iteration. After the 50 iterations, we examine the values of subsidies and taxes after each iteration to ensure that they have reached stable values by end whose changes from iteration 49 to 50 are approaching $\$ 0$ on average for all U.S. states (i.e., examining patterns of changes for each sequential pair of iterations) and are very small in the last pair of iterations (i.e., $<\$ 1$ on average for each state between iteration 49 and 50 ).

Finally, with the values of the federal subsidies and cost-sharing estimated along with the change in taxes for each household at the $50^{\text {th }}$ iteration, we can compute the State and Local Government income supplement to offset the difference between health insurance premium payments as:

$$
S L G_{\text {supplement }}=P-S_{2}+\Delta \tau
$$




\section{Additional Results and Supplemental Analyses}

\section{8a. Status Quo Estimates}

Appendix Table 6 shows the estimates of the total healthcare costs for households of SLGs workers and retirees below the age 65 as a proxy for their premium costs. As noted in the manuscript, we assume that SLGs cover $80 \%$ of the premium costs and hence have scaled Appendix Table 6 accordingly, hence representing the costs borne by the SLGs. These estimates represent the status quo costs against which potential savings and additional costs to SLGs of various divestment strategies are benchmarked. Likewise, Appendix Table 7 shows the percentage of households of SLG current workers and retirees below the age of 65 that fall below important Federal Poverty Level thresholds (i.e., those for which ACA federal subsidies and cost-sharing would apply; those for which federal support of Medicaid expansions would apply if the state implements such an expansion). Of note, under various divestment strategies that involve transfers to workers or retirees from SLGs in the form of income supplements in lieu of providing health insurance directly, these percentages can change in ways that shift eligibility and sizes of subsidies and of cost-sharing (see Appendix Section 7 above on the dynamic calculation of these levels).

Appendix Table 6. Estimated Total Premium Costs (in $\mathbf{\$ 1 , 0 0 0 , 0 0 0 s )}$ for Households of State and Local Government Current Workers and Retirees under Age 65

\begin{tabular}{|l|r|r|}
\hline State & Current Workers & Retirees \\
\hline Alabama & 2,253 & 488 \\
\hline Alaska & 494 & 99 \\
\hline Arizona & 2,177 & 425 \\
\hline Arkansas & 916 & 132 \\
\hline California & 13,876 & 2,044 \\
\hline Colorado & 1,778 & 391 \\
\hline Connecticut & 1,647 & 309 \\
\hline Delaware & 319 & 67 \\
\hline District Of Columbia & 117 & 17 \\
\hline Florida & 5,836 & 1,091 \\
\hline Georgia & 3,664 & 803 \\
\hline Hawaii & 565 & 172 \\
\hline Idaho & 717 & 117 \\
\hline Illinois & 4,746 & 980 \\
\hline Indiana & 2,337 & 352 \\
\hline Iowa & 1,690 & 310 \\
\hline Kansas & 1,690 & 263 \\
\hline Kentucky & 1,596 & 533 \\
\hline Louisiana & 1,558 & 398 \\
\hline Maine & 586 & 151 \\
\hline Maryland & 2,319 & 430 \\
\hline Massachusetts & 2,936 & 479 \\
\hline Michigan & 3,498 & 861 \\
\hline Minnesota & 2,253 & 438 \\
\hline Mississippi & 1,412 & 350 \\
\hline Missouri & 2,379 & 426 \\
\hline Montana & 414 & 76 \\
\hline Nebraska & 982 & 154 \\
\hline Nevada & 930 & 228 \\
\hline
\end{tabular}




\begin{tabular}{|l|r|r|}
\hline New Hampshire & 565 & 110 \\
\hline New Jersey & 4,027 & 524 \\
\hline New Mexico & 822 & 224 \\
\hline New York & 9,908 & 1,702 \\
\hline North Carolina & 4,195 & 844 \\
\hline North Dakota & 369 & 53 \\
\hline Ohio & 4,454 & 905 \\
\hline Oklahoma & 1,442 & 214 \\
\hline Oregon & 1,557 & 488 \\
\hline Pennsylvania & 4,307 & 1,244 \\
\hline Rhode Island & 426 & 113 \\
\hline South Carolina & 1,855 & 603 \\
\hline South Dakota & 352 & 62 \\
\hline Tennessee & 2,060 & 243 \\
\hline Texas & 9,198 & 1,556 \\
\hline Utah & 893 & 145 \\
\hline Vermont & 300 & 62 \\
\hline Virginia & 2,574 & 399 \\
\hline Washington & 2,920 & 478 \\
\hline West Virginia & 926 & 165 \\
\hline Wisconsin & 2,606 & 622 \\
\hline Wyoming & 368 & 58 \\
\hline NATIONAL & $\mathbf{1 2 1 , 8 0 7}$ & $\mathbf{2 3 , 3 9 8}$ \\
\hline 10 YEARS & $\mathbf{1 , 2 1 8 , 0 6 6}$ & $\mathbf{2 3 3 , 9 8 0}$ \\
\hline
\end{tabular}


Appendix Table 7. Household Incomes Relative to the 2013 Federal Poverty Line (FPL) for Current Workers and Retirees from State and Local Governments under 65 Years of Age

\begin{tabular}{|c|c|c|c|c|}
\hline \multirow[b]{2}{*}{ State } & \multicolumn{2}{|c|}{ Current Workers } & \multicolumn{2}{|c|}{ Retirees } \\
\hline & $\begin{array}{c}\% \text { between } \\
138-400 \% \\
\text { of FPL }\end{array}$ & $\begin{array}{c}\% \text { below } \\
138 \% \\
\text { of FPL }\end{array}$ & $\begin{array}{c}\% \text { between } \\
138-400 \% \\
\text { of FPL }\end{array}$ & $\begin{array}{c}\% \text { below } \\
138 \% \\
\text { of FPL }\end{array}$ \\
\hline Alabama & $47 \%$ & $5 \%$ & $28 \%$ & $2 \%$ \\
\hline Alaska & $47 \%$ & $3 \%$ & $44 \%$ & $5 \%$ \\
\hline Arizona & $51 \%$ & $3 \%$ & $27 \%$ & $8 \%$ \\
\hline Arkansas & $47 \%$ & $5 \%$ & $54 \%$ & $9 \%$ \\
\hline California & $35 \%$ & $3 \%$ & $29 \%$ & $2 \%$ \\
\hline Colorado & $36 \%$ & $4 \%$ & $31 \%$ & $2 \%$ \\
\hline Connecticut & $31 \%$ & $1 \%$ & $17 \%$ & $0 \%$ \\
\hline Delaware & $36 \%$ & $3 \%$ & $32 \%$ & $5 \%$ \\
\hline District Of Columbia & $33 \%$ & $2 \%$ & $47 \%$ & $10 \%$ \\
\hline Florida & $43 \%$ & $3 \%$ & $34 \%$ & $3 \%$ \\
\hline Georgia & $50 \%$ & $7 \%$ & $31 \%$ & $2 \%$ \\
\hline Hawaii & $50 \%$ & $4 \%$ & $30 \%$ & $5 \%$ \\
\hline Idaho & $50 \%$ & $3 \%$ & $40 \%$ & $0 \%$ \\
\hline Illinois & $34 \%$ & $1 \%$ & $23 \%$ & $0 \%$ \\
\hline Indiana & $45 \%$ & $3 \%$ & $51 \%$ & $5 \%$ \\
\hline Iowa & $38 \%$ & $2 \%$ & $29 \%$ & $2 \%$ \\
\hline Kansas & $46 \%$ & $7 \%$ & $28 \%$ & $3 \%$ \\
\hline Kentucky & $46 \%$ & $6 \%$ & $36 \%$ & $0 \%$ \\
\hline Louisiana & $47 \%$ & $7 \%$ & $33 \%$ & $18 \%$ \\
\hline Maine & $40 \%$ & $1 \%$ & $42 \%$ & $2 \%$ \\
\hline Maryland & $29 \%$ & $3 \%$ & $36 \%$ & $2 \%$ \\
\hline Massachusetts & $26 \%$ & $2 \%$ & $17 \%$ & $7 \%$ \\
\hline Michigan & $34 \%$ & $2 \%$ & $34 \%$ & $0 \%$ \\
\hline Minnesota & $34 \%$ & $1 \%$ & $30 \%$ & $2 \%$ \\
\hline Mississippi & $48 \%$ & $10 \%$ & $45 \%$ & $4 \%$ \\
\hline Missouri & $46 \%$ & $2 \%$ & $39 \%$ & $6 \%$ \\
\hline Montana & $43 \%$ & $3 \%$ & $29 \%$ & $10 \%$ \\
\hline Nebraska & $42 \%$ & $2 \%$ & $36 \%$ & $3 \%$ \\
\hline Nevada & $39 \%$ & $1 \%$ & $27 \%$ & $0 \%$ \\
\hline New Hampshire & $29 \%$ & $1 \%$ & $21 \%$ & $6 \%$ \\
\hline New Jersey & $24 \%$ & $1 \%$ & $32 \%$ & $3 \%$ \\
\hline New Mexico & $40 \%$ & $9 \%$ & $45 \%$ & $7 \%$ \\
\hline New York & $36 \%$ & $3 \%$ & $33 \%$ & $5 \%$ \\
\hline North Carolina & $44 \%$ & $3 \%$ & $31 \%$ & $2 \%$ \\
\hline North Dakota & $35 \%$ & $2 \%$ & $22 \%$ & $0 \%$ \\
\hline Ohio & $43 \%$ & $2 \%$ & $35 \%$ & $8 \%$ \\
\hline Oklahoma & $48 \%$ & $5 \%$ & $35 \%$ & $12 \%$ \\
\hline Oregon & $39 \%$ & $3 \%$ & $29 \%$ & $0 \%$ \\
\hline Pennsylvania & $32 \%$ & $1 \%$ & $31 \%$ & $2 \%$ \\
\hline Rhode Island & $25 \%$ & $1 \%$ & $20 \%$ & $3 \%$ \\
\hline South Carolina & $40 \%$ & $4 \%$ & $48 \%$ & $3 \%$ \\
\hline South Dakota & $49 \%$ & $2 \%$ & $34 \%$ & $0 \%$ \\
\hline Tennessee & $46 \%$ & $6 \%$ & $35 \%$ & $10 \%$ \\
\hline Texas & $48 \%$ & $5 \%$ & $33 \%$ & $2 \%$ \\
\hline Utah & $47 \%$ & $3 \%$ & $17 \%$ & $0 \%$ \\
\hline Vermont & $34 \%$ & $1 \%$ & $41 \%$ & $2 \%$ \\
\hline Virginia & $38 \%$ & $3 \%$ & $35 \%$ & $10 \%$ \\
\hline Washington & $38 \%$ & $1 \%$ & $47 \%$ & $2 \%$ \\
\hline
\end{tabular}




\begin{tabular}{|l|c|c|c|c|}
\hline West Virginia & $47 \%$ & $4 \%$ & $34 \%$ & $4 \%$ \\
\hline Wisconsin & $42 \%$ & $4 \%$ & $29 \%$ & $3 \%$ \\
\hline Wyoming & $41 \%$ & $2 \%$ & $41 \%$ & $6 \%$ \\
\hline NATIONAL & $\mathbf{4 0 \%}$ & $\mathbf{3 \%}$ & $\mathbf{3 3 \%}$ & $\mathbf{3 \%}$ \\
\hline
\end{tabular}




\section{8b. Full Divestment Strategy}

We consider the Full Divestment Strategy in the context of current state Medicaid expansions which would be federally supported under the ACA. Columns in the tables generally show individual components of savings (costs) that the strategies induce. For the current Medicaid expansion scenarios in states that have not expanded Medicaid, we make two assumptions: 1) no savings from federal support for Medicaid expansions; 2) SLGs in states without Medicaid expansions increase compensation to households below 138\% of the FPL so that their household falls at $138 \%$ of the FPL and hence they qualify for maximal exchange subsidies and costsharing. For current workers, assumption \#2 induces some increases in federal taxes that the SLGs must also offset because of increased incomes. The component costs and savings are shown in Appendix Tables 8-9.

In the Full Divestment Strategy, we sum the component savings and costs for current worker and retiree subgroups. Then, for each state, we subtract employer penalties (approximately $\$ 2,000$ per worker times the number of workers in Appendix Table 1) to compute the net savings (or cost) (Appendix Table 10). We repeat this step examining a set of hypotheticals in which the employer penalty per worker is lowered or even $\$ 0$. The relevance of these hypotheticals is that some smaller to mid-size SLGs may face a lower per-worker employer penalty than $\$ 2,000$ given that the penalty is levied for workers above the first 30 . Additionally, the $\$ 0$ penalty may be relevant if SLGs were to successfully challenge the applicability of the penalty to them.

We also consider the Full Divestment Strategy under a hypothetical scenario in which all states implement Medicaid expansions. These results are shown in Appendix Tables 11-13. Note that in the full Medicaid expansion scenario, SLGs do not increase the household incomes of those below 138\% of FPL up to 138\% since those falling below 138\% of FPL qualify for federal support under Medicaid which produces larger savings for the SLGs. 
Appendix Table 8. Component Savings and Costs from Divestment for Current Employees Assuming Current Medicaid Expansions Only (\$1,000,000s)

\begin{tabular}{|c|c|c|c|c|}
\hline & $\begin{array}{l}\text { Savings from } \\
\text { Federal } \\
\text { Government } \\
\text { Subsidies and } \\
\text { Cost-Sharing }\end{array}$ & $\begin{array}{l}\text { Savings from } \\
\text { Federal Support } \\
\text { of Medicaid } \\
\text { Expansions* }\end{array}$ & $\begin{array}{c}\text { Additional Federal } \\
\text { Taxes Compensated } \\
\text { by State and Local } \\
\text { Governments }\end{array}$ & $\begin{array}{c}\text { Additional } \\
\text { Compensation to bring } \\
\text { Household below } 138 \% \\
\text { of the Federal Poverty } \\
\text { Level up to That Level* }\end{array}$ \\
\hline Alabama & 587 & 0 & 406 & 17 \\
\hline Alaska & 72 & 0 & 110 & 1 \\
\hline Arizona & 585 & 83 & 386 & 0 \\
\hline Arkansas & 255 & 58 & 143 & 0 \\
\hline California & 2,169 & 479 & 3,026 & 0 \\
\hline Colorado & 275 & 75 & 393 & 0 \\
\hline Connecticut & 197 & 23 & 359 & 0 \\
\hline Delaware & 48 & 9 & 64 & 0 \\
\hline District of Columbia & 20 & 1 & 28 & 0 \\
\hline Florida & 1,207 & 0 & 1,095 & 43 \\
\hline Georgia & 956 & 0 & 642 & 76 \\
\hline Hawaii & 105 & 30 & 108 & 0 \\
\hline Idaho & 174 & 0 & 117 & 3 \\
\hline Illinois & 621 & 69 & 968 & 0 \\
\hline Indiana & 483 & 0 & 373 & 14 \\
\hline Iowa & 221 & 37 & 304 & 0 \\
\hline Kansas & 287 & 0 & 270 & 27 \\
\hline Kentucky & 403 & 95 & 266 & 0 \\
\hline Louisiana & 473 & 0 & 274 & 21 \\
\hline Maine & 87 & 0 & 113 & 2 \\
\hline Maryland & 299 & 83 & 533 & 0 \\
\hline Massachusetts & 289 & 52 & 647 & 0 \\
\hline Michigan & 436 & 69 & 707 & 0 \\
\hline Minnesota & 220 & 14 & 446 & 0 \\
\hline Mississippi & 416 & 0 & 216 & 23 \\
\hline Missouri & 434 & 0 & 408 & 4 \\
\hline Montana & 91 & 0 & 76 & 3 \\
\hline Nebraska & 147 & 0 & 176 & 3 \\
\hline Nevada & 127 & 6 & 194 & 0 \\
\hline New Hampshire & 56 & 0 & 117 & 4 \\
\hline New Jersey & 418 & 35 & 930 & 0 \\
\hline New Mexico & 181 & 81 & 142 & 0 \\
\hline New York & 1,396 & 430 & 2,006 & 0 \\
\hline North Carolina & 1,035 & 0 & 748 & 34 \\
\hline North Dakota & 39 & 10 & 70 & 0 \\
\hline Ohio & 801 & 100 & 799 & 0 \\
\hline Oklahoma & 336 & 0 & 240 & 22 \\
\hline Oregon & 295 & 52 & 300 & 0 \\
\hline Pennsylvania & 507 & 0 & 893 & 14 \\
\hline Rhode Island & 38 & 7 & 96 & 0 \\
\hline South Carolina & 371 & 0 & 335 & 4 \\
\hline South Dakota & 62 & 0 & 60 & 3 \\
\hline Tennessee & 473 & 0 & 344 & 34 \\
\hline Texas & 2,141 & 0 & 1,609 & 130 \\
\hline Utah & 213 & 0 & 174 & 4 \\
\hline Vermont & 33 & 3 & 58 & 0 \\
\hline Virginia & 427 & 0 & 514 & 5 \\
\hline
\end{tabular}




\begin{tabular}{|l|r|r|r|r|}
\hline Washington & 457 & 33 & 605 & 0 \\
\hline West Virginia & 208 & 43 & 149 & 0 \\
\hline Wisconsin & 387 & 0 & 473 & 12 \\
\hline Wyoming & 64 & 0 & 71 & 1 \\
\hline
\end{tabular}

* For states without Medicaid expansions, savings from federal support of Medicaid is $\$ 0$ but additional savings are captured by increasing the household incomes of workers falling below $138 \%$ of the federal poverty lines up to $138 \%$ such that these households qualify for federal subsidies and cost-sharing for exchange-purchased plans. 
Appendix Table 9. Component Savings and Costs from Divestment for Retirees under Age 65 Assuming Current Medicaid Expansions Only $\mathbf{( \$ 1 , 0 0 0 , 0 0 0 s )}$

\begin{tabular}{|c|c|c|c|}
\hline+2 & $\begin{array}{l}\text { Savings from Federal } \\
\text { Government Subsidies } \\
\text { and Cost-Sharing }\end{array}$ & $\begin{array}{l}\text { Savings from Federal } \\
\text { Support of Medicaid } \\
\text { Expansions* }\end{array}$ & $\begin{array}{c}\text { Additional Compensation to bring } \\
\text { Household below } 138 \% \text { of the } \\
\text { Federal Poverty Level up to That } \\
\text { Level* }\end{array}$ \\
\hline Alabama & 52 & 0 & 5 \\
\hline Alaska & 11 & 0 & 0 \\
\hline Arizona & 42 & 33 & 0 \\
\hline Arkansas & 23 & 16 & 0 \\
\hline California & 175 & 27 & 0 \\
\hline Colorado & 32 & 6 & 0 \\
\hline Connecticut & 12 & 0 & 0 \\
\hline Delaware & 4 & 4 & 0 \\
\hline $\begin{array}{l}\text { District of } \\
\text { Columbia }\end{array}$ & 2 & 2 & 0 \\
\hline Florida & 133 & 0 & 0 \\
\hline Georgia & 68 & 0 & 1 \\
\hline Hawaii & 18 & 16 & 0 \\
\hline Idaho & 12 & 0 & 0 \\
\hline Illinois & 23 & 0 & 0 \\
\hline Indiana & 37 & 0 & 2 \\
\hline Iowa & 10 & 5 & 0 \\
\hline Kansas & 15 & 0 & 0 \\
\hline Kentucky & 33 & 0 & 0 \\
\hline Louisiana & 49 & 0 & 7 \\
\hline Maine & 12 & 0 & 1 \\
\hline Maryland & 31 & 7 & 0 \\
\hline Massachusetts & 16 & 17 & 0 \\
\hline Michigan & 48 & 0 & 0 \\
\hline Minnesota & 14 & 7 & 0 \\
\hline Mississippi & 36 & 0 & 3 \\
\hline Missouri & 34 & 0 & 10 \\
\hline Montana & 10 & 0 & 0 \\
\hline Nebraska & 7 & 0 & 0 \\
\hline Nevada & 11 & 0 & 0 \\
\hline $\begin{array}{l}\text { New } \\
\text { Hampshire }\end{array}$ & 5 & 0 & 2 \\
\hline New Jersey & 43 & 8 & 0 \\
\hline New Mexico & 25 & 15 & 0 \\
\hline New York & 132 & 83 & 0 \\
\hline North Carolina & 91 & 0 & 0 \\
\hline North Dakota & 2 & 0 & 0 \\
\hline Ohio & 54 & 46 & 0 \\
\hline Oklahoma & 18 & 0 & 4 \\
\hline Oregon & 25 & 0 & 0 \\
\hline Pennsylvania & 95 & 0 & 9 \\
\hline Rhode Island & 5 & 3 & 0 \\
\hline South Carolina & 81 & 0 & 0 \\
\hline South Dakota & 5 & 0 & 0 \\
\hline Tennessee & 32 & 0 & 11 \\
\hline Texas & 140 & 0 & 3 \\
\hline Utah & 8 & 0 & 0 \\
\hline Vermont & 5 & 2 & 0 \\
\hline
\end{tabular}




\begin{tabular}{|l|r|r|r|}
\hline Virginia & 43 & 0 & 6 \\
\hline Washington & 24 & 8 & 0 \\
\hline West Virginia & 15 & 9 & 0 \\
\hline Wisconsin & 15 & 0 & 0 \\
\hline Wyoming & 9 & 0 & 0 \\
\hline
\end{tabular}

* For states without Medicaid expansions, savings from federal support of Medicaid is $\$ 0$ but additional savings are captured by increasing the household incomes of workers falling below $138 \%$ of the federal poverty lines up to $138 \%$ such that these households qualify for federal subsidies and cost-sharing for exchange-purchased plans. 
Appendix Table 10. Savings from Divestment for Current Employees and Retirees under Age 65 Assuming Current Medicaid Expansions Only and Depending on Employer Penalty Level (\$1,000,000s)*

\begin{tabular}{|c|c|c|c|c|c|}
\hline & $\begin{array}{l}\text { Savings } \\
\text { with } \\
\text { Employer } \\
\text { Penalty } \\
\text { of } \\
\$ 2,000 * \\
\end{array}$ & $\begin{array}{c}\text { Savings } \\
\text { with } \\
\text { Employer } \\
\text { Penalty of } \\
\$ 1,750\end{array}$ & $\begin{array}{c}\text { Savings } \\
\text { with } \\
\text { Employer } \\
\text { Penalty of } \\
\$ 1,500\end{array}$ & $\begin{array}{l}\text { Savings } \\
\text { with } \\
\text { Employer } \\
\text { Penalty of } \\
\$ 1,000\end{array}$ & $\begin{array}{c}\text { Savings } \\
\text { with } \\
\text { Employer } \\
\text { Penalty of } \\
\$ 0\end{array}$ \\
\hline Alabama & -224 & -170 & -116 & -7 & 210 \\
\hline Alaska & -134 & -121 & -107 & -81 & -28 \\
\hline Arizona & -87 & -32 & 24 & 135 & 357 \\
\hline Arkansas & 19 & 43 & 66 & 114 & 209 \\
\hline California & $-2,970$ & $-2,621$ & $-2,272$ & $-1,573$ & -176 \\
\hline Colorado & -402 & -352 & -302 & -203 & -4 \\
\hline Connecticut & -423 & -386 & -349 & -275 & -127 \\
\hline Delaware & -59 & -52 & -44 & -29 & 1 \\
\hline District of Columbia & -35 & -31 & -27 & -19 & -3 \\
\hline Florida & $-1,069$ & -910 & -751 & -433 & 203 \\
\hline Georgia & -445 & -351 & -257 & -70 & 305 \\
\hline Hawaii & -45 & -32 & -19 & 8 & 61 \\
\hline Idaho & -95 & -75 & -55 & -15 & 65 \\
\hline Illinois & $-1,107$ & $-1,001$ & -894 & -681 & -255 \\
\hline Indiana & -263 & -213 & -164 & -66 & 131 \\
\hline Iowa & -331 & -294 & -256 & -181 & -31 \\
\hline Kansas & -299 & -261 & -223 & -146 & 7 \\
\hline Kentucky & -80 & -37 & 6 & 92 & 264 \\
\hline Louisiana & -102 & -62 & -22 & 59 & 220 \\
\hline Maine & -123 & -110 & -97 & -70 & -17 \\
\hline Maryland & -585 & -526 & -467 & -349 & -113 \\
\hline Massachusetts & -805 & -739 & -672 & -539 & -273 \\
\hline Michigan & -752 & -677 & -603 & -453 & -154 \\
\hline Minnesota & -571 & -523 & -476 & -381 & -191 \\
\hline Mississippi & -104 & -65 & -25 & 53 & 210 \\
\hline Missouri & -379 & -326 & -273 & -166 & 47 \\
\hline Montana & -66 & -55 & -44 & -22 & 22 \\
\hline Nebraska & -196 & -175 & -153 & -110 & -24 \\
\hline Nevada & -240 & -217 & -193 & -145 & -50 \\
\hline New Hampshire & -157 & -145 & -133 & -109 & -61 \\
\hline New Jersey & $-1,107$ & $-1,022$ & -937 & -766 & -425 \\
\hline New Mexico & -19 & 3 & 26 & 71 & 161 \\
\hline New York & $-1,807$ & $-1,577$ & $-1,346$ & -886 & 35 \\
\hline North Carolina & -604 & -485 & -367 & -130 & 344 \\
\hline North Dakota & -87 & -79 & -70 & -53 & -19 \\
\hline Ohio & -592 & -492 & -393 & -195 & 202 \\
\hline Oklahoma & -233 & -193 & -153 & -72 & 89 \\
\hline Oregon & -273 & -230 & -187 & -100 & 73 \\
\hline Pennsylvania & $-1,151$ & $-1,046$ & -942 & -733 & -315 \\
\hline Rhode Island & -116 & -107 & -98 & -79 & -42 \\
\hline South Carolina & -278 & -229 & -181 & -83 & 112 \\
\hline South Dakota & -62 & -54 & -46 & -29 & 4 \\
\hline Tennessee & -302 & -249 & -197 & -93 & 116 \\
\hline Texas & $-1,457$ & $-1,208$ & -958 & -458 & 541 \\
\hline Utah & -138 & -116 & -93 & -47 & 44 \\
\hline Vermont & -68 & -62 & -55 & -41 & -14 \\
\hline
\end{tabular}




\begin{tabular}{|l|r|r|r|r|r|}
\hline Virginia & $\mathbf{- 5 8 8}$ & -521 & -455 & -322 & -56 \\
\hline Washington & $\mathbf{- 7 1 6}$ & -637 & -558 & -400 & -84 \\
\hline West Virginia & $\mathbf{- 6 0}$ & -37 & -14 & 33 & 126 \\
\hline Wisconsin & $\mathbf{- 5 3 9}$ & -482 & -425 & -311 & -83 \\
\hline Wyoming & $\mathbf{- 7 9}$ & -69 & -59 & -39 & 1 \\
\hline NATIONAL* & $\mathbf{1 9}$ & $\mathbf{4 6}$ & $\mathbf{1 2 2}$ & $\mathbf{5 6 5}$ & $\mathbf{4 , 1 6 0}$ \\
\hline 10 YEARS* & $\mathbf{1 9 0}$ & $\mathbf{4 6 0}$ & $\mathbf{1 , 2 2 0}$ & $\mathbf{5 , 6 5 0}$ & $\mathbf{4 1 , 6 0 0}$ \\
\hline
\end{tabular}

* The first column of estimates (\$2,000 employer penalty per worker) is shown in bold as it is the assumption made in the main analyses as shown in the manuscript. 
Appendix Table 11. Component Savings and Costs from Divestment for Current Employees Assuming Medicaid Expansions in All States $\mathbf{( \$ 1 , 0 0 0 , 0 0 0 s )}$

\begin{tabular}{|c|c|c|c|}
\hline & $\begin{array}{c}\text { Savings from Federal } \\
\text { Government Subsidies and } \\
\text { Cost-Sharing }\end{array}$ & $\begin{array}{l}\text { Savings from Federal } \\
\text { Support of Medicaid } \\
\text { Expansions }\end{array}$ & $\begin{array}{l}\text { Additional Federal Taxes } \\
\text { Compensated by State and } \\
\text { Local Governments }\end{array}$ \\
\hline Alabama & 551 & 156 & 403 \\
\hline Alaska & 71 & 19 & 109 \\
\hline Arizona & 585 & 83 & 386 \\
\hline Arkansas & 255 & 58 & 143 \\
\hline California & 2,169 & 479 & 3,026 \\
\hline Colorado & 275 & 75 & 393 \\
\hline Connecticut & 197 & 23 & 359 \\
\hline Delaware & 48 & 9 & 64 \\
\hline $\begin{array}{l}\text { District of } \\
\text { Columbia }\end{array}$ & 20 & 1 & 28 \\
\hline Florida & 1,185 & 233 & 1,090 \\
\hline Georgia & 932 & 282 & 632 \\
\hline Hawaii & 105 & 30 & 108 \\
\hline Idaho & 174 & 25 & 117 \\
\hline Illinois & 621 & 69 & 968 \\
\hline Indiana & 463 & 78 & 371 \\
\hline Iowa & 221 & 37 & 304 \\
\hline Kansas & 287 & 120 & 266 \\
\hline Kentucky & 403 & 95 & 266 \\
\hline Louisiana & 473 & 130 & 272 \\
\hline Maine & 85 & 7 & 112 \\
\hline Maryland & 299 & 83 & 533 \\
\hline Massachusetts & 289 & 52 & 647 \\
\hline Michigan & 436 & 69 & 707 \\
\hline Minnesota & 220 & 14 & 446 \\
\hline Mississippi & 401 & 158 & 212 \\
\hline Missouri & 434 & 38 & 408 \\
\hline Montana & 90 & 14 & 76 \\
\hline Nebraska & 146 & 16 & 175 \\
\hline Nevada & 127 & 6 & 194 \\
\hline New Hampshire & 56 & 7 & 117 \\
\hline New Jersey & 418 & 35 & 930 \\
\hline New Mexico & 181 & 81 & 142 \\
\hline New York & 1,396 & 430 & 2,006 \\
\hline North Carolina & 1,030 & 158 & 743 \\
\hline $\begin{array}{l}\text { North Dakota } \\
\end{array}$ & 39 & 10 & 70 \\
\hline Ohio & 801 & 100 & 799 \\
\hline Oklahoma & 331 & 89 & 237 \\
\hline Oregon & 295 & 52 & 300 \\
\hline Pennsylvania & 501 & 54 & 892 \\
\hline Rhode Island & 38 & 7 & 96 \\
\hline South Carolina & 371 & 97 & 335 \\
\hline South Dakota & 57 & 12 & 59 \\
\hline Tennessee & 473 & 141 & 340 \\
\hline Texas & 2,106 & 564 & 1,588 \\
\hline Utah & 205 & 39 & 173 \\
\hline Vermont & 33 & 3 & 58 \\
\hline Virginia & 414 & 95 & 513 \\
\hline Washington & 457 & 33 & 605 \\
\hline
\end{tabular}




\begin{tabular}{|l|r|r|r|}
\hline West Virginia & 208 & 43 & 149 \\
\hline Wisconsin & 387 & 136 & 471 \\
\hline Wyoming & 62 & 10 & 70 \\
\hline
\end{tabular}


Appendix Table 12. Component Savings and Costs from Divestment for Retirees under Age 65 Assuming Medicaid Expansions in All States $\mathbf{( \$ 1 , 0 0 0 , 0 0 0 s )}$

\begin{tabular}{|c|c|c|}
\hline & $\begin{array}{c}\text { Savings from } \\
\text { Federal Government } \\
\text { Subsidies and Cost-Sharing }\end{array}$ & $\begin{array}{c}\text { Savings from } \\
\text { Federal Support of } \\
\text { Medicaid Expansions }\end{array}$ \\
\hline Alabama & $\begin{array}{ll} & 52 \\
\end{array}$ & 9 \\
\hline Alaska & 10 & 5 \\
\hline Arizona & 42 & 33 \\
\hline Arkansas & 23 & 16 \\
\hline California & 175 & 27 \\
\hline Colorado & 32 & 6 \\
\hline Connecticut & 12 & 0 \\
\hline Delaware & 4 & 4 \\
\hline District of Columbia & 2 & 2 \\
\hline Florida & 125 & 29 \\
\hline Georgia & 68 & 6 \\
\hline Hawaii & 18 & 16 \\
\hline Idaho & 12 & 0 \\
\hline Illinois & 23 & 0 \\
\hline Indiana & 37 & 8 \\
\hline Iowa & 10 & 5 \\
\hline Kansas & 15 & 4 \\
\hline Kentucky & 33 & 0 \\
\hline Louisiana & 43 & 70 \\
\hline Maine & 12 & 3 \\
\hline Maryland & 31 & 7 \\
\hline Massachusetts & 16 & 17 \\
\hline Michigan & 48 & 0 \\
\hline Minnesota & 14 & 7 \\
\hline Mississippi & 36 & 7 \\
\hline Missouri & 20 & 22 \\
\hline Montana & 10 & 5 \\
\hline Nebraska & 7 & 5 \\
\hline Nevada & 11 & 0 \\
\hline New Hampshire & 5 & 7 \\
\hline New Jersey & 43 & 8 \\
\hline New Mexico & 25 & 15 \\
\hline New York & 132 & 83 \\
\hline North Carolina & 81 & 18 \\
\hline North Dakota & 2 & 0 \\
\hline Ohio & 54 & 46 \\
\hline Oklahoma & 9 & 26 \\
\hline Oregon & 25 & 0 \\
\hline Pennsylvania & 95 & 20 \\
\hline Rhode Island & 5 & 3 \\
\hline South Carolina & 81 & 12 \\
\hline South Dakota & 5 & 0 \\
\hline Tennessee & 32 & 11 \\
\hline Texas & 140 & 21 \\
\hline Utah & 8 & 0 \\
\hline Vermont & 5 & 2 \\
\hline Virginia & 43 & 40 \\
\hline Washington & 24 & 8 \\
\hline West Virginia & 15 & 9 \\
\hline
\end{tabular}




\begin{tabular}{|l|r|r|}
\hline Wisconsin & 8 & 13 \\
\hline Wyoming & 7 & 4 \\
\hline
\end{tabular}


Appendix Table 13. Savings from Divestment for Current Employees and Retirees under Age 65 Assuming Medicaid Expansions in All States and Depending on Employer Penalty Level (\$1,000,000s)*

\begin{tabular}{|c|c|c|c|c|c|}
\hline & $\begin{array}{c}\text { Savings } \\
\text { with } \\
\text { Employer } \\
\text { Penalty } \\
\text { of } \\
\$ 2,000 \\
\end{array}$ & $\begin{array}{c}\text { Savings } \\
\text { with } \\
\text { Employer } \\
\text { Penalty } \\
\text { of } \\
\$ 1,750 \\
\end{array}$ & $\begin{array}{c}\text { Savings } \\
\text { with } \\
\text { Employer } \\
\text { Penalty } \\
\text { of } \\
\$ 1,500 \\
\end{array}$ & $\begin{array}{c}\text { Savings } \\
\text { with } \\
\text { Employer } \\
\text { Penalty } \\
\text { of } \\
\$ 1,000 \\
\end{array}$ & $\begin{array}{c}\text { Savings } \\
\text { with } \\
\text { Employer } \\
\text { Penalty } \\
\text { of } \\
\$ 0 \\
\end{array}$ \\
\hline Alabama & -69 & -15 & 39 & 148 & 365 \\
\hline Alaska & -111 & -98 & -84 & -58 & -5 \\
\hline Arizona & -87 & -32 & 24 & 135 & 357 \\
\hline Arkansas & 19 & 43 & 66 & 114 & 209 \\
\hline California & $-2,970$ & $-2,621$ & $-2,272$ & $-1,573$ & -176 \\
\hline Colorado & -402 & -352 & -302 & -203 & -4 \\
\hline Connecticut & -423 & -386 & -349 & -275 & -127 \\
\hline Delaware & -59 & -52 & -44 & -29 & 1 \\
\hline District of Columbia & -35 & -31 & -27 & -19 & -3 \\
\hline Florida & -790 & -631 & -472 & -154 & 482 \\
\hline Georgia & -94 & -1 & 93 & 281 & 656 \\
\hline Hawaii & -45 & -32 & -19 & 8 & 61 \\
\hline Idaho & -67 & -47 & -27 & 13 & 93 \\
\hline Illinois & $-1,107$ & $-1,001$ & -894 & -681 & -255 \\
\hline Indiana & -178 & -129 & -79 & 19 & 216 \\
\hline Iowa & -331 & -294 & -256 & -181 & -31 \\
\hline Kansas & -145 & -107 & -69 & 8 & 161 \\
\hline Kentucky & -80 & -37 & 6 & 92 & 264 \\
\hline Louisiana & 123 & 163 & 203 & 284 & 445 \\
\hline Maine & -112 & -98 & -85 & -59 & -6 \\
\hline Maryland & -585 & -526 & -467 & -349 & -113 \\
\hline Massachusetts & -805 & -739 & -672 & -539 & -273 \\
\hline Michigan & -752 & -677 & -603 & -453 & -154 \\
\hline Minnesota & -571 & -523 & -476 & -381 & -191 \\
\hline Mississippi & 75 & 114 & 154 & 232 & 389 \\
\hline Missouri & -319 & -266 & -213 & -106 & 107 \\
\hline Montana & -45 & -34 & -23 & -1 & 43 \\
\hline Nebraska & -173 & -151 & -130 & -87 & -1 \\
\hline Nevada & -240 & -217 & -193 & -145 & -50 \\
\hline New Hampshire & -138 & -126 & -114 & -90 & -42 \\
\hline New Jersey & $-1,107$ & $-1,022$ & -937 & -766 & -425 \\
\hline New Mexico & -19 & 3 & 26 & 71 & 161 \\
\hline New York & $-1,807$ & $-1,577$ & $-1,346$ & -886 & 35 \\
\hline North Carolina & -404 & -286 & -167 & 70 & 544 \\
\hline North Dakota & -87 & -79 & -70 & -53 & -19 \\
\hline Ohio & -592 & -492 & $\begin{array}{l}-393 \\
\end{array}$ & -195 & 202 \\
\hline Oklahoma & -104 & -64 & -24 & 57 & 218 \\
\hline Oregon & -273 & -230 & -187 & -100 & 73 \\
\hline Pennsylvania & $-1,059$ & -954 & -850 & -641 & -223 \\
\hline Rhode Island & -116 & -107 & -98 & -79 & -42 \\
\hline South Carolina & -164 & -115 & -66 & 31 & 226 \\
\hline South Dakota & -51 & -43 & -35 & -18 & 15 \\
\hline Tennessee & -100 & -48 & 4 & 109 & 318 \\
\hline Texas & -756 & -506 & -257 & 243 & 1,242 \\
\hline Utah & -102 & -80 & -57 & -11 & 80 \\
\hline Vermont & -68 & -62 & -55 & -41 & -14 \\
\hline
\end{tabular}




\begin{tabular}{|l|r|r|r|r|r|}
\hline Virginia & $\mathbf{- 4 5 3}$ & -387 & -320 & -187 & 79 \\
\hline Washington & $\mathbf{- 7 1 6}$ & -637 & -558 & -400 & -84 \\
\hline West Virginia & $\mathbf{- 6 0}$ & -37 & -14 & 33 & 126 \\
\hline Wisconsin & $\mathbf{- 3 8 3}$ & -326 & -269 & -155 & 73 \\
\hline Wyoming & $\mathbf{- 6 8}$ & -58 & -48 & -28 & 12 \\
\hline NATIONAL* & $\mathbf{2 1 7}$ & $\mathbf{3 2 3}$ & $\mathbf{6 1 5}$ & $\mathbf{1 , 9 4 8}$ & $\mathbf{7 , 2 5 3}$ \\
\hline 10 YEARS* $^{*}$ & $\mathbf{2 , 1 7 0}$ & $\mathbf{3 , 2 3 0}$ & $\mathbf{6 , 1 5 0}$ & $\mathbf{1 9 , 4 8 0}$ & $\mathbf{7 2 , 5 3 0}$ \\
\hline
\end{tabular}

* The first column of estimates (\$2,000 employer penalty per worker) is shown in bold as it is the assumption made in the main analyses as shown in the manuscript. 


\section{8c. Selective Divestment Strategy}

We consider the Selective Divestment Strategy in the context of current state Medicaid expansions which would be federally supported under the ACA. Columns in the tables generally show individual components of savings (costs) that the strategies induce. For the current Medicaid expansion scenarios in states that have not expanded Medicaid, we make two assumptions: 1) no savings from federal support for Medicaid expansions; 2) SLGs in states without Medicaid expansions increase compensation to households below 138\% of the FPL so that their household falls at 138\% of the FPL and hence they qualify for maximal exchange subsidies and cost-sharing. For current workers, assumption \#2 induces some increases in federal taxes that the SLGs must also offset because of increased incomes. The component costs and savings for current workers are shown in Appendix Tables 14. Of note, since full divestment for retirees under age 65 is cost saving and no employer penalties are relevant to this subgroup, we use the data presented in Appendix Table 9 for the retiree portion of this strategy as well.

In the Selective Divestment Strategy, we sum the component savings and costs for current worker and retiree subgroups. Unlike the Full Divestment Strategy, penalties are assessed for workers who qualify for federal subsidies or cost-sharing, so these penalty estimates are reported in the tables directly. Of note, like the Full Divestment Strategy, a \$0 penalty may be relevant if SLGs were to successfully challenge the applicability of the penalty to them - if so, the component costs and savings could be summed omitting the employer penalty column.

We also consider the Selective Divestment Strategy under a hypothetical scenario in which all states implement Medicaid expansions. These results are shown in Appendix Tables 15, with those relevant to retirees the same as Appendix Table 12. Note that in the full Medicaid expansion scenario, SLGs do not increase the household incomes of those below 138\% of FPL up to $138 \%$ since those falling below $138 \%$ of FPL qualify for federal support under Medicaid which produces larger savings for the SLGs. 
Appendix Table 14. Component Savings and Costs from Selective Divestment for Current Employees below $400 \%$ of the Federal Poverty Level Assuming Current Medicaid Expansions Only $\mathbf{( \$ 1 , 0 0 0 , 0 0 0 s )}$

\begin{tabular}{|c|c|c|c|c|c|}
\hline & $\begin{array}{l}\text { Savings from } \\
\text { Federal } \\
\text { Government } \\
\text { Subsidies and } \\
\text { Cost-Sharing }\end{array}$ & $\begin{array}{l}\text { Savings from } \\
\text { Federal } \\
\text { Support of } \\
\text { Medicaid } \\
\text { Expansions* }\end{array}$ & $\begin{array}{c}\text { Additional } \\
\text { Federal Taxes } \\
\text { Compensated by } \\
\text { State and Local } \\
\text { Governments }\end{array}$ & $\begin{array}{l}\text { Employer } \\
\text { Penalties Paid } \\
\text { to the Federal } \\
\text { Government }\end{array}$ & $\begin{array}{c}\text { Additional } \\
\text { Compensation to } \\
\text { bring Household } \\
\text { below } 138 \% \text { of the } \\
\text { Federal Poverty } \\
\text { Level up to That } \\
\text { Level* } \\
\end{array}$ \\
\hline Alabama & 576 & 0 & 52 & 239 & 17 \\
\hline Alaska & 70 & 0 & 16 & 39 & 1 \\
\hline Arizona & 578 & 83 & 60 & 234 & 0 \\
\hline Arkansas & 244 & 58 & 13 & 90 & 0 \\
\hline California & 2,132 & 479 & 282 & 940 & 0 \\
\hline Colorado & 272 & 75 & 33 & 127 & 0 \\
\hline Connecticut & 195 & 23 & 25 & 84 & 0 \\
\hline Delaware & 48 & 9 & 6 & 23 & 0 \\
\hline $\begin{array}{l}\text { District of } \\
\text { Columbia }\end{array}$ & 19 & 1 & 2 & 10 & 0 \\
\hline Florida & 1,163 & 0 & 107 & 531 & 43 \\
\hline Georgia & 943 & 0 & 103 & 404 & 76 \\
\hline Hawaii & 101 & 30 & 19 & 49 & 0 \\
\hline Idaho & 171 & 0 & 15 & 74 & 3 \\
\hline Illinois & 601 & 69 & 84 & 279 & 0 \\
\hline Indiana & 482 & 0 & 50 & 201 & 14 \\
\hline Iowa & 218 & 37 & 30 & 104 & 0 \\
\hline Kansas & 282 & 0 & 39 & 135 & 27 \\
\hline Kentucky & 393 & 95 & 29 & 166 & 0 \\
\hline Louisiana & 462 & 0 & 42 & 189 & 21 \\
\hline Maine & 86 & 0 & 11 & 40 & 2 \\
\hline Maryland & 292 & 83 & 32 & 127 & 0 \\
\hline Massachusetts & 289 & 52 & 35 & 125 & 0 \\
\hline Michigan & 432 & 69 & 57 & 192 & 0 \\
\hline Minnesota & 217 & 14 & 36 & 109 & 0 \\
\hline Mississippi & 400 & 0 & 36 & 168 & 23 \\
\hline Missouri & 426 & 0 & 54 & 189 & 4 \\
\hline Montana & 90 & 0 & 8 & 36 & 3 \\
\hline Nebraska & 145 & 0 & 20 & 69 & 3 \\
\hline Nevada & 127 & 6 & 23 & 65 & 0 \\
\hline $\begin{array}{l}\text { New } \\
\text { Hampshire }\end{array}$ & 56 & 0 & 7 & 28 & 4 \\
\hline New Jersey & 414 & 35 & 48 & 177 & 0 \\
\hline New Mexico & 181 & 81 & 16 & 83 & 0 \\
\hline New York & 1,379 & 430 & 185 & 637 & 0 \\
\hline $\begin{array}{l}\text { North } \\
\text { Carolina }\end{array}$ & 1,016 & 0 & 88 & 437 & 34 \\
\hline North Dakota & 37 & 10 & 7 & 21 & 0 \\
\hline Ohio & 773 & 100 & 92 & 329 & 0 \\
\hline Oklahoma & 329 & 0 & 32 & 141 & 22 \\
\hline Oregon & 287 & 52 & 31 & 131 & 0 \\
\hline Pennsylvania & 494 & 0 & 72 & 247 & 14 \\
\hline Rhode Island & 37 & 7 & 6 & 17 & 0 \\
\hline $\begin{array}{l}\text { South } \\
\text { Carolina }\end{array}$ & 362 & 0 & 38 & 172 & 4 \\
\hline
\end{tabular}




\begin{tabular}{|c|c|c|c|c|c|}
\hline South Dakota & 61 & 0 & 10 & 31 & 3 \\
\hline Tennessee & 449 & 0 & 42 & 203 & 34 \\
\hline Texas & 2,099 & 0 & 234 & 902 & 130 \\
\hline Utah & 211 & 0 & 22 & 81 & 4 \\
\hline Vermont & 33 & 3 & 4 & 15 & 0 \\
\hline Virginia & 418 & 0 & 61 & 208 & 5 \\
\hline Washington & 445 & 33 & 57 & 202 & 0 \\
\hline West Virginia & 207 & 43 & 19 & 94 & 0 \\
\hline Wisconsin & 382 & 0 & 54 & 176 & 12 \\
\hline Wyoming & 61 & 0 & 7 & 29 & 1 \\
\hline
\end{tabular}

* For states without Medicaid expansions, savings from federal support of Medicaid is \$0 but additional savings are captured by increasing the household incomes of workers falling below $138 \%$ of the federal poverty lines up to $138 \%$ such that these households qualify for federal subsidies and cost-sharing for exchange-purchased plans. 
Appendix Table 15. Component Savings and Costs from Selective Divestment for Current Employees below $400 \%$ of the Federal Poverty Level Assuming Medicaid Expansions in All States (\$1,000,000s)

\begin{tabular}{|c|c|c|c|c|}
\hline & $\begin{array}{c}\text { Savings from } \\
\text { Federal Government } \\
\text { Subsidies and Cost- } \\
\text { Sharing } \\
\end{array}$ & $\begin{array}{c}\text { Savings from } \\
\text { Federal Support of } \\
\text { Medicaid } \\
\text { Expansions } \\
\end{array}$ & $\begin{array}{c}\text { Additional Federal } \\
\text { Taxes Compensated by } \\
\text { State and Local } \\
\text { Governments } \\
\end{array}$ & $\begin{array}{l}\text { Employer Penalties } \\
\text { Paid to the Federal } \\
\text { Government }\end{array}$ \\
\hline Alabama & 541 & 156 & 51 & 233 \\
\hline Alaska & 69 & 19 & 16 & 39 \\
\hline Arizona & 578 & 83 & 60 & 234 \\
\hline Arkansas & 244 & 58 & 13 & 90 \\
\hline California & 2,132 & 479 & 282 & 940 \\
\hline Colorado & 272 & 75 & 33 & 127 \\
\hline Connecticut & 195 & 23 & 25 & 84 \\
\hline Delaware & 48 & 9 & 6 & 23 \\
\hline $\begin{array}{l}\text { District of } \\
\text { Columbia }\end{array}$ & 19 & 1 & 2 & 10 \\
\hline Florida & 1,143 & 233 & 107 & 523 \\
\hline Georgia & 921 & 282 & 102 & 398 \\
\hline Hawaii & 101 & 30 & 19 & 49 \\
\hline Idaho & 171 & 25 & 15 & 74 \\
\hline Illinois & 601 & 69 & 84 & 279 \\
\hline Indiana & 462 & 78 & 49 & 197 \\
\hline Iowa & 218 & 37 & 30 & 104 \\
\hline Kansas & 282 & 120 & 39 & 135 \\
\hline Kentucky & 393 & 95 & 29 & 166 \\
\hline Louisiana & 462 & 130 & 42 & 189 \\
\hline Maine & 84 & 7 & 11 & 40 \\
\hline Maryland & 292 & 83 & 32 & 127 \\
\hline Massachusetts & 289 & 52 & 35 & 125 \\
\hline Michigan & 432 & 69 & 57 & 192 \\
\hline Minnesota & 217 & 14 & 36 & 109 \\
\hline Mississippi & 385 & 158 & 36 & 165 \\
\hline Missouri & 426 & 38 & 54 & 189 \\
\hline Montana & 88 & 14 & 7 & 36 \\
\hline Nebraska & 143 & 16 & 20 & 68 \\
\hline Nevada & 127 & 6 & 23 & 65 \\
\hline $\begin{array}{l}\text { New } \\
\text { Hampshire }\end{array}$ & 56 & 7 & 7 & 28 \\
\hline New Jersey & 414 & 35 & 48 & 177 \\
\hline New Mexico & 181 & 81 & 16 & 83 \\
\hline New York & 1,379 & 430 & 185 & 637 \\
\hline North Carolina & 1,011 & 158 & 88 & 434 \\
\hline North Dakota & 37 & 10 & 7 & 21 \\
\hline Ohio & 773 & 100 & 92 & 329 \\
\hline Oklahoma & 323 & 89 & 32 & 140 \\
\hline Oregon & 287 & 52 & 31 & 131 \\
\hline Pennsylvania & 488 & 54 & 71 & 245 \\
\hline Rhode Island & 37 & 7 & 6 & 17 \\
\hline South Carolina & 362 & 97 & 38 & 172 \\
\hline South Dakota & 56 & 12 & 10 & 30 \\
\hline Tennessee & 449 & 141 & 42 & 203 \\
\hline Texas & 2,063 & 564 & 231 & 897 \\
\hline Utah & 203 & 39 & 21 & 80 \\
\hline Vermont & 33 & 3 & 4 & 15 \\
\hline
\end{tabular}




\begin{tabular}{|l|r|r|r|r|}
\hline Virginia & 405 & 95 & 60 & 206 \\
\hline Washington & 445 & 33 & 57 & 202 \\
\hline West Virginia & 207 & 43 & 19 & 94 \\
\hline Wisconsin & 382 & 136 & 54 & 176 \\
\hline Wyoming & 59 & 10 & 7 & 29 \\
\hline
\end{tabular}




\section{8d. Comparison of Healthcare Costs of Employee Households Shifting to Coverage under}

Exchange Plans and Those Continuing on State and Local Government-Provided Plans with the Selective Divestment Strategy

We examine the projections of total household healthcare costs for groups of employee households defined in terms of whether they are subsidy eligible and hence would receive coverage under exchange-purchased plans in the selective divestment strategy. In general, for most states, the projections of total healthcare spending we use in our analysis are reasonably similar in magnitude, though slightly higher on average for SLG employee households falling below 400\% of the Federal Poverty Level (likely to qualify for subsidies, cost-sharing, or Medicaid) compared SLG employee households above this level. Notable large state exceptions include California and New York where those below 400\% have lower total healthcare spending on average. Note that these comparisons are made on total healthcare spending and not just the share of these costs covered by the SLG employers.

Appendix Table 16. Average Annual Household Healthcare Expenditures Projected for Employee Households Shifting to Coverage under Exchange Plans and Those Continuing on State and Local Government-Provided Plans with the Selective Divestment Strategy

\begin{tabular}{|l|c|c|}
\hline & $\begin{array}{c}\text { Shifting to } \\
\text { Exchange Plans } \\
\text { ( } \mathbf{4 0 0 \% \text { of }} \\
\text { Federal Poverty Level) }\end{array}$ & $\begin{array}{c}\text { Continuing on } \\
\text { Employer Provided Plans } \\
\text { ( } \mathbf{4 0 0 \% \text { of }} \\
\text { Federal Poverty Level) }\end{array}$ \\
\hline Alabama & 13,605 & 12,120 \\
\hline Alaska & 12,686 & 12,649 \\
\hline Arizona & 12,978 & 12,616 \\
\hline Arkansas & 13,307 & 12,045 \\
\hline California & 13,198 & 13,400 \\
\hline Colorado & 12,475 & 11,290 \\
\hline Connecticut & 14,256 & 15,349 \\
\hline Delaware & 13,745 & 12,719 \\
\hline District of Columbia & 8,990 & 10,039 \\
\hline Florida & 12,554 & 11,570 \\
\hline Georgia & 12,729 & 12,355 \\
\hline Hawaii & 14,245 & 14,609 \\
\hline Idaho & 13,249 & 12,104 \\
\hline Illinois & 14,881 & 13,367 \\
\hline Indiana & 15,317 & 14,150 \\
\hline Iowa & 15,863 & 13,603 \\
\hline Kansas & 15,601 & 13,988 \\
\hline Kentucky & 12,891 & 11,438 \\
\hline Louisiana & 12,129 & 12,095 \\
\hline Maine & 14,988 & 14,279 \\
\hline Maryland & 12,930 & 12,671 \\
\hline Massachusetts & 14,238 & 14,577 \\
\hline Michigan & 15,395 & 14,705 \\
\hline Minnesota & 16,349 & 14,587 \\
\hline Mississippi & 13,063 & 11,686 \\
\hline Missouri & 16,388 & 13,374 \\
\hline Montana & 13,188 & 11,552 \\
\hline Nebraska & 16,415 & 13,438 \\
\hline Nevada & 12,927 & 13,056 \\
\hline New Hampshire & 15,206 & 13,934 \\
\hline & & \\
\hline
\end{tabular}




\begin{tabular}{|l|c|c|}
\hline New Jersey & 15,262 & 14,124 \\
\hline New Mexico & 12,581 & 11,274 \\
\hline New York & 13,895 & 14,338 \\
\hline North Carolina & 12,865 & 11,880 \\
\hline North Dakota & 15,682 & 12,977 \\
\hline Ohio & 15,562 & 13,714 \\
\hline Oklahoma & 12,704 & 12,215 \\
\hline Oregon & 12,268 & 11,764 \\
\hline Pennsylvania & 13,763 & 12,973 \\
\hline Rhode Island & 14,674 & 15,190 \\
\hline South Carolina & 13,010 & 11,925 \\
\hline South Dakota & 14,358 & 13,808 \\
\hline Tennessee & 13,673 & 12,110 \\
\hline Texas & 12,800 & 12,713 \\
\hline Utah & 14,151 & 12,637 \\
\hline Vermont & 15,120 & 13,579 \\
\hline Virginia & 12,716 & 12,436 \\
\hline Washington & 12,950 & 12,290 \\
\hline West Virginia & 13,539 & 11,891 \\
\hline Wisconsin & 15,196 & 14,391 \\
\hline Wyoming & 12,760 & 12,057 \\
\hline
\end{tabular}

